DOI: https://doi.org/10.31933/jimt.v2i4 Received: 22 Februari 2021, Revised: 10 Maret 2021, Publish: 17 Maret 2021

JIMT
JURNAL ILMU MANAJEMEN
TERAPAN

\title{
LITERATURE REVIEW: MODEL PENGUKURAN KINERJA DOSEN DAN ORGANIZATIONAL CITIZENSHIP BEHAVIOR BERDASARKAN KARAKTERISTIK INDIVIDU, BUDAYA KERJA DAN PERILAKU INDIVIDU
}

\author{
Ramdani Bayu Putra' ${ }^{1)}$, Hasmaynelis Fitri²) \\ ${ }^{1)}$ Mahasiswa Program Doktor, Universitas Putra Indonesia YPTK Padang, ramdhani_bayu@ upiyptk.ac.id \\ ${ }^{2)}$ Universitas Putra Indonesia YPTK Padang. hasmay@upiyptk.ac.id
}

\section{Corresponding Author: Ramdani Bayu Putra}

\begin{abstract}
Pengembangan suatu penelitian peran dari riset terdahulu atau riset yang relevan adalah sangat penting, karenakan dapat membantu dan berfungsi untuk memperkuat kajian teoritis dan fenomena hubungan atau pengaruh antar variabel dalam suatu penelitian. Artikel ini mereview dan berupaya untuk mengkonfirmasi faktor-faktor yang mempengaruhi kinerja Dosen dan organizational citizenship behavior (OCB) yang meliputi karakter individu, budaya organisasi dan Perilaku individu. Studi literatur Manajemen Sumberdaya Manusia hasil dari library risearch adalah bahwa: 1). Karakteristik individu berpengaruh terhadap kinerja dosen; 2). Budaya kerja berpengaruh terhadap kinerja dosen; 3) perilaku individu berpengaruh terhadap kinerja dosen; 4). organizational citizenship behavior berpengaruh terhadap kinerja dosen; 5). Karakteristik individu berpengaruh terhadap organizational citizenship behavior; 6). Budaya kerja berpengaruh terhadap organizational citizenship behavior; 7). Perilaku individu berpengaruh terhadap organizational citizenship behavior; 8). Karakteristik individu berpengaruh terhadap kinerja dosen melalui organizational citizenship behavior; 9). Budaya kerja berpengaruh terhadap kinerja dosen melalui organizational citizenship behavior; dan 10). Perilaku individu berpengaruh terhadap kinerja dosen melalui organizational citizenship behavior
\end{abstract}

Keyword: Karakteristik individu, Budaya kerja, Perilaku individu, Organizational citizenship behavior, dan Kinerja Dosen

\section{PENDAHULUAN}

\section{Latar Belakang Masalah.}

Tuntutan perkembangan dan kemajuan ilmu pengetahuan sangat bergantung kepada yang namanya penelitian. Untuk itu keberlanjutan penelitian harus selalu dilakukan untuk menemukan kajian teori yang nantinya dapat berdampak terhadap kemanfaatannya secara praktis dalam kehidupan masyarakat luas. Atas dasar itu sebagai seorang tenaga pendidik, dosen harus dapat memenuhi pengabdiannya dalam Tridarma Perguruan Tinggi, salah satunya 
adalah melakukan penelitian. Melalui pengamatan dan data diketahui suatu permasalahan atau fenomena dalam bidang ilmu tertentu yang melalui kaidah-kaidah yang berlaku dosen mampu menulis karya ilmiah atau riset dengan memadukannya melalui pengetahuan dan keterampilannya dalam memahami, menganalisis, menggambarkan, dan menjelaskan masalah yang berhubungan dengan faktor-faktor tertentu yang saling berkaitan dalam bidang keilmuan.

Namun sayangnya berdasarkan pengalaman empirik banyak peneliti seperti dosen dan mahasiswa mengalami kesulitan dalam mencari artikel pendukung yang relevan untuk karya ilmiahnya sebagai dasar penelitiannya. Artikel peneliti yang relevan sangat diperlukan untuk memperkuat dan mengembangkan kajian teoritis, yang berguna untuk melihat hubungan antar variable tertentu untuk membangun hipotesis dan pembahasan dari hasil penelitian. Riset ini secara spesifik akan membahas faktor Karakteristik individu $\left(\mathrm{X}_{1}\right)$, Budaya kerja $\left(\mathrm{X}_{2}\right)$, dan Perilaku individu yang bepengaruh terhadap kinerja dosen $\left(\mathrm{Y}_{1}\right)$ dan Organizational citizenship behavior $\left(\mathrm{Y}_{2}\right)$ dalam studi literatur manajemen sumberdaya manusia. Tentu masih banyak faktor lain yang juga dapat menjelaskan dan mempengaruhi terhadap kinerja dosen $\left(\mathrm{Y}_{1}\right)$ dan Organizational citizenship behavior $\left(\mathrm{Y}_{2}\right)$. Namun dalam kajian review ini lebih fokus kepada hal atau permasalahan yang telah dijelaskan di atas.

\section{Rumusan Masalah.}

Berdasarkan permasalahan di atas, dapat dirumuskan beberapa masalah yang akan di bahas pada riset literatur review, agar lebih focus pada kajian pustaka dan hasil serta pembahasan nanti, yaitu:

1) Apakah karakteristik individu berpengaruh terhadap kinerja dosen?

2) Apakah budaya kerja berpengaruh terhadap kinerja dosen?

3) Apakah perilaku individu berpengaruh terhadap kinerja dosen?

4) Apakah organizational citizenship behavior berpengaruh terhadap kinerja dosen?

5) Apakah karakteristik individu berpengaruh terhadap organizational citizenship behavior?

6) Apakah budaya kerja berpengaruh terhadap organizational citizenship behavior?

7) Apakah perilaku individu berpengaruh terhadap organizational citizenship behavior?

8) Apakah karakteristik individu berpengaruh terhadap kinerja dosen melalui organizational citizenship behavior?

9) Apakah budaya kerja berpengaruh terhadap kinerja dosen melalui organizational citizenship behavior?

10) Apakah perilaku individu berpengaruh terhadap kinerja dosen melalui organizational citizenship behavior?

\section{KAJIAN PUSTAKA}

\section{Kinerja Karyawan}

Kinerja merupakan output atau hasil kerja yang dihasilkan seorangpegawai atau karyawan dalam suatu organisasi atau perusahaan, (Afuan et al., 2020; R B Putra, 2016; R B Putra et al., 2020), (Prayetno \& Ali, 2017). Sedangkan Colquitt et al, (2011) menyatakan bahwa kinerja adalah nilai serangkaian perilaku pekerja yang memberikan kontribusi, baik secara positif maupun negatif, ada penyelesaian tujuan organisasi. Mangkunegara (2011), kinerja 
merupakan hasil kerja secara kualitas dan kuantitas yang dicapai oleh seorang karyawan dalam melaksanakan tugasnya sesuai dengan tanggung jawab yang diberikan kepadanya. Wibowo (2010), kinerja adalah tentang melakukan pekerjaan dan hasil yang dicapai dari pekerjaan tersebut. Kinerja adalah tentang apa yang dikerjakan dan bagaimana cara mengerjakannya.

Mangkunegara (2011), menyatakan bahwa faktor-faktor yang dapat mempengaruhi kinerja adalah:

1) Faktor kemampuan (ability. Secara psikologis, kemampuan (ability) pegawai terdiri dari kemampuan potensi (IQ) dan kemampuan reality (knowledge + skill). Artinya pegawai yang memiliki IQ di atas rata-rata (IQ 110-120) dengan pendidikan yang memadai untuk jabatannya dan terampil dalam mengerjakan pekerjaan sehari-hari, maka ia akan lebih mudah mencapai kinerja yang diharapkan. Oleh karena itu, pegawai perlu ditempatkan pada pekerjaan yang sesuai dengan keahliannya.

2) Faktor motivasi. Motivasi terbentuk dari sikap (attitude) seseorang pegawai dalam menghadapi situasi (situation) kerja. Motivasi merupakan kondisi yang menggerakkan diri pegawai yang terarah untuk mencapai tujuan organisasi (tujuan kerja). Sikap mental merupakan kondisi mental yang mendorong diri pegawai untuk berusaha mencapai prestasi kerja secara maksimal. Sikap mental pegawai harus sikap mental yang secara psikofisik (siap secara mental, fisik, tujuan,dan situasi), artinya seorang pegawai harus siap secara mental, mampu secara fisik, memahami secara fisik, memahami tujuan utama dari target kerja yang akan dicapai, mampu memanfaatkan, dan menciptakan situasi kerja.

Sedangkan menurut Wibowo (2010) faktor-faktor yang mempengaruhi kinerja sumber daya manusia meliputi:

1) Faktor internal pegawai, yaitu faktor-faktor dari dalam diri pegawai yang merupakan faktor bawaan dari lahir dan faktor yang diperoleh ketika ia berkembang. Faktor-faktor bawaan, misalnya bakat, sifat pribadi, serta keadaan fisik dan kejiwaan. Sementara itu, faktor yang diperoleh, misalnya seperti pengetahuan, ketrampilan, etos kerja, pengalaman kerja, dan motivasi kerja.

2) Faktor lingkungan internal organisasi. Dalam melaksanakan tugasnya, pegawai memerlukan dukungan organisasi tempat ia bekerja. Dukungan tersebut sangat mempengaruhi tinggi rendahkan kinerja pegawai. Faktor internal organisasi antara lain teknologi robot, sistem kompensasi, iklim kerja, strategi organisasi, dukungan sumber daya yang diperlukan untuk melaksanakan pekerjaan, serta sistem manajemen dan kompensasi

3) Faktor lingkungan eksternal organisasi. Faktor-faktor lingkungan eksternal organisasi adalah keadaan, kejadian, atau situasi yang terjadi di lingkungan ekternal organisasi, misalnya krisis ekonomi.

Berdasarkan kajian teoritis yang telah dijelaskan diatas, penulis menyimpulkan bahwa faktor-faktor yang mempengaruhi kinerja individu dalam organisasi dapat bersumber dari faktor internal dan faktor eksternal. Faktor internal adalah faktor yang berkaitan langsung dengan individu atau personal seperti karakteristik individu perilaku individu. Sedangkan faktor eksternal adalah faktor atau unsur yang berasal dari luar diri individu seperti, lingkungan, peristiwa, kebijakan pemerintah, budaya kerja dan lain-lain.Literatur lain, Mitchel dalam Sedarmayanti \& Rahadian (2018), kinerja karyawan dapat di ukur melalui: 1) Quality of work (Kualitas hasil kerja); 2) Promptness (Ketepatan waktu); 3) Initiative (Prakarsa dalam menyelesaikan tugas); 4) Capability (Kemampuan menyelesaikan tugas); dan 5) Communication (Kemampuan menjalin kerjasama dengan pihak lain). 
Penelitian terkait kinerja pegawai telah banyak dilakukan oleh para peneliti diantaranya adalah: (Prihartono \& Ali, 2020), (Harini et al., 2020), ), (Brata, Husani, Hapzi, 2017), (Desfiandi et al., 2017), (Sulaeman et al., 2019), (Riyanto, Sutrisno, et al., 2017), (Prayetno \& Ali, 2017), (Ridwan et al., 2020), (Djoko Setyo Widodo, P. Eddy Sanusi Silitonga, 2017), , (Afuan et al., 2020; R B Putra, 2016; R B Putra et al., 2020), (M. Ali, 2018; Cesário, 2017; Diamantidis, 2019; Papa, 2018)

\section{Organizational Citizenship Behavior (OCB)}

Organizational Citizenship Behavior (OCB) atau kewarganegaraan organisasional merupakan bagian dari ilmu perilaku organisasi. Sedangkan dasar sikap mengidentifikasikan bahwa karyawan terlibat dalam OCB untuk membalas tindakan organisasi, (Luthan, 2009). Perilaku Kewarganegaraan Organisasional (organizational citizenship behavior) adalah perilaku yang merupakan pilihan dan inisiatif individual, tidak berkaitan dengan sistem reward formal organisasi tetapi secara agregat meningkatkan efektivitas organisasi. Hal ini berarti perilaku tersebut tidak termasuk kedalam persyaratan kerja atau deskripsi kerja karyawan sehingga jika tidak ditampilkan pun tidak diberikan hukuman, (Organ, 1988).

Menurut Robbins (2008), organizational citizenship behavior (OCB) adalah perilaku pilihan yang tidak menjadi bagian dari kewajiban kerja formal seorang karyawan, namun mendukung berfungsinya organisasi tersebut secara efektif. Dengan kata lain Organizational Citizenship Behavior (OCB) merupakan perilaku yang bersifat sukarela, bukan merupakan tindakan yang terpaksa terhadap hal-hal yang mengedepankan kepentingan organisasi atau perilaku individu sebagai wujud dari kepuasan berdasarkan kinerja yang dihasilkan (performance), tidak diperintahkan secara formal dan tidak berkaitan secara langsung dan terang-terangan dengan sistem reward yang formal dalam rangka meningkatkan pencapaian kinerja dan mendukung pengembangan organisasi, (Ridwan et al., 2020) (R B Putra, 2016), (R B Putra, 2018).

Dalam tiga dekade terakhir, organizational citizenship behaviour (OCB) semakin mendapat perhatian dari para akademisi dan praktisi dalam menelaah dan menganalisis lebih lanjut gagasan perilaku ini dan dampaknya terhadap bidang perilaku organisasi, (Takeuchi, 2015). Diantara banyak indikator yang menentukan terwujudnya kinerja karyawan itu adalah kualitas kerja, tingkat kegigihan kerja, tingkat kehadiran, kerjasama antar rekan kerja, tingkat kepedulian terhadap keselamatan kerja, tanggung jawab terhadap hasil kerjanya, dan kreativitas yang semua itu ada hubungannya dengan organizational citizenship behaviour (OCB), (Fauth et al., 2009). Boyatzis \& Ron (2001) dalam (Munawir, 2019) menyatakan bahwa menemukan orang yang tepat dalam organisasi tidaklah mudah karena yang dibutuhkan bukan hanya orang yang berpendidikan lebih baik atau orang yang bertalenta. Namun, terdapat faktor psikologis yang mendasari hubungan antara seseorang dengan organisasinya. Hal tersebut dibuktikan dengan hasil studi yang dilakukan oleh (MacKenzie et al., 1998) yang menunjukkan bahwa OCB berperan dalam meningkatkan kinerja. Dimensi OCB menurut (Organ, 1988) :

a) Altruism, Perilaku karyawan dalam menolong rekan kerjanya yang mengalami kesulitan dalam situasi yang sedang dihadapi baik mengenai tugas dalam organisasi maupun masalah pribadi orang lain. Dimensi ini mengarah kepada memberi pertolongan yang bukan merupakan kewajiban yang ditanggungnya. 
b) Conscientiousness, Perilaku yang ditunjukkan dengan berusaha melebihi yang diharapkan perusahaan. Perilaku sukarela yang bukan merupakan kewajiban atau tugas karyawan. Dimensi ini menjangkau jauh diatas dan jauh ke depan dari panggilan tugas.

a) Sportmanship, Perilaku yang memberikan toleransi terhadap keadaan yang kurang ideal dalam organisasi tanpa mengajukan keberatan-keberatan. Seseorang yang mempunyai tingkatan yang tinggi dalam sportmanship akan meningkatkan iklim yang positif diantara karyawan, karyawan akan lebih sopan dan bekerja sama dengan yang lain sehingga akan menciptakan lingkungan kerja yang lebih menyenangkan.

d) Courtessy, Menjaga hubungan baik dengan rekan kerjanya agar terhindar dari masalahmasalah interpersonal. Seseorang yang memiliki dimensi ini adalah orang yang menghargai dan memperhatikan orang lain, yaitu membantu teman kerja, mencegah timbulnya masalah sehubungan dengan pekerjannya dengan cara memberi konsultasi dan informasi serta menghargai kebutuhan mereka.

e) Civic Virtue, Perilaku yang mengindikasikan tanggung jawab pada kehidupan organisasi (mengikuti perubahan dalam organisasi, mengambil inisiatif untuk merekomendasikan bagaimana operasi atau prosedur-rosedur organisasi dapat diperbaiki, dan melindungi sumber- sumber yang dimiliki oleh organisasi). Dimensi ini mengarah pada tanggung jawab yang diberikan organisasi kepada seorang untuk meningkatkan kualitas bidang pekerjaan yang ditekuni.

Penelitian terdahulu yang telah melakukan penelitian tentang organizational citizenship behavior (OCB) adalah (Astakhova, 2015; Bottomley, 2016; Chan, 2017; Hui, 2015; Indarti, 2017; Koning, 2015; Lavy, 2017; Li, 2016; Mo, 2017; Ng, 2016) (Ridwan et al., 2020) (R B Putra, 2016), (R B Putra, 2018), (Alsheikh, 2019; Banwo, 2020; Chidir, 2020; Desky, 2020; Gunnesch-Luca, 2020; Munawir, 2019; Nugroho, 2020; Nurjanah, 2020; L. Ocampo, 2018; Teng, 2020; T. Wang, 2018), (Alsheikh, 2019; Barus, 2018; Chidir, 2020; Marinda, 2019; Rejeki, 2019; Sukarman, 2018; T. Wang, 2018; Wasiman, 2019; Yodsuwan, 2020)

\section{Karakteristik Individu}

Karakteristik individu adalah perbedaan individu dengan individu lainnya. Sumber daya yang terpenting dalam organisasi adalah sumber daya manusia, orang-orang yang memberikan tenaga, bakat, kreativitas, dan usaha mereka kepada organisasi agar suatu organisasi dapat tetap eksistensinya (Peoni, 2014). Karakteristik individu adalah ciri khas atau sifat khusus yang dimiliki karyawan yang dapat menjadikan dirinya memiliki kemampuan yang berbeda dengan karyawan yang lainnya untuk mempertahankan dan memperbaiki kinerjanya, (Aktarina, 2019). Menurut Ardana dkk, bahwa karakteristik individu adalah minat, sikap terhadap diri sendiri, pekerjaan, dan situasi pekerjaan, kebutuhan individual, kemampuan atau kompetensi, pengetahuan tentang pekerjaan dan emosi, suasana hati, perasaan keyakinan dan nilai-nilai, (Setiawan \& Bodroastuti, 2010). Robbins (2008), menyatakan bahwa karakteristik individu seperti umur, masa kerja, dan status pernikahan dapat mempengaruhi kinerja individu.

Penelitian terkai karakteristik sudah banyak di teliti oleh peneliti sebelumnya diantaranya adalah: ( Aktarina, 2019; Ananda \& Sunuharyo, 2018; Arifudin \& Rusmana, 2020; Handayati, 2016; Mariniharsi et al., 2020; Prasetyowati et al., 2019; Rahman et al., 2020; Rasmikayati et 
al., 2020; Ratnasari et al., 2020), (Alsheikh, 2019; Banwo, 2020; Barus, 2018; Batilmurik, 2020; Gunnesch-Luca, 2020; Nugroho, 2020; L. A. Ocampo, 2018; Raj, 2016; Rejeki, 2019; Sidin, 2020; Subardjo, 2020; Susita, 2020; T. Wang, 2018; Wasiman, 2019).

\section{Budaya Kerja}

Budaya kerja adalah suatu filsafah yang didasari oleh pandangan hidup sebagai nilai-nilai yang menjadi sifat, kebiasaan dan kekuatan pendorong, membudaya dalam kehidupan suatu kelompok masyarakat atau organisasi, kemudian tercermin dari sikap menjadi perilaku, kepercayaan, cita-cita, pendapat dan tindakan yang terwujud sebagai "kerja" atau "bekerja" (Triguno, 1995). Budaya yang kuat adalah bahwa budaya itu akan meningkatkan perilaku yang konsisten. Budaya itu menyampaikan kepada pegawai tentang bagaimana perilaku yang seharusnya Seorang anggota akan mau berpartisipasi, bila yang bersangkutan mengetahui tujuan organisasi tersebut, manfaat terhadap dirinya, dan cara organisasi itu dalam mencapai tujuan, Robbins (2008).

Indikator-indikator budaya kerja tenaga pengajar adalah sebagai berikut: (1) kondisi lingkungan fisik pekerjaan, meliputi: pemberian penghargaan, pemberian kesejahteraan, terpenuhi prasarana dan sarana. (2) kondisi lingkungan pekerjaan, meliputi: dukungan dalam menjalankan tugas, dapat merancang dan mendesain pekerjaan, pengawasan dan disiplin kerja, komunikasi dan interaksi dengan teman sejawat, orang tua siswa, kepala sekolah/rektor dan lingkungan masyarakat, fungsi kepemimpinan kepala sekolah, menetapkan kebijakan secara personil, program sekolah sesuai dengan sifat dan tujuan, menetapkan kebijakan kompensasi dan pengelolaan sekolah, Robbins (2008). Schein (2010), mendefinisikan budaya sebagai suatu pola asumsi dasar bersama yang dipelajari kelompok tertentu untuk mengatasi masalah adaptasi eksternal dan integrasi internal. Lima faktor yang mempengaruhi budaya kerja yaitu tanggung jawab karyawan, inovasi, orientasi pada hasil, pengetahuan dan sistem kerja. Faktor-faktor tersebut secara langsung akan mempengaruhi budaya kerja karyawan dalam suatu perusahaan atau organisasi. Hal ini sudah sesuai dengan penelitian yang dilakukan (Shodiyah, 2017) menyatakan budaya kerja berpengaruh signifikan terhadap kinerja karyawan.

Penelitian terkait budaya kerja sudah banyak di teliti oleh peneliti sebelumnya diantaranya adalah: (Anthoni \& Faisal, 2020; Astutik \& Priantono, 2020; Driyantini et al., 2020; Gozali et al., 2020; Gumilar, 2020; Hamzah \& Sarwoko, 2020; Iman \& Prasetyo, 2019; Indriapati et al., 2020; F. Kurniawan, 2019; Lambey et al., 2020; Nasution, 2020; Norisanti et al., 2020; Oktiani et al., 2019; Paulus, 2019; D. Putra et al., 2020; Sanjaya, 2020; Saputri \& Syaifullah, 2020; Shodiyah, 2017; Syarif et al., 2020; Tokhayatun, 2020; Victor, 2020;

Wakhyuni \& Dalimunthe, 2020; Yunita, 2020).

\section{Perilaku Individu}

Perilaku merupakan keseluruhan atau totalitas kegiatan akibat belajar dari pengalaman sebelumnya dan dipelajari melalui proses penguatan dan pengkondisian, (Adair et al., 2016). Perilaku menurut Miftah (2015), adalah suatu fungsi dari interaksi antara seseorang dengan lingkungannya, sedangkan perilaku individu adalah fungsi dari interaksi antara person atau individu dengan lingkungannya. Jika dikaitkan dengan perilaku organisasi maka perilaku individu merupakan sebagai suatu sistem studi dari sifat organisasi seperti misalnya bagaimana 
organisasi dimulai, tumbuh dan berkembang dan bagaimana pengaruh terhadap anggotaanggota sebagai individu, kelompok-kelompok pemilih, organisasi-organisasi lainnya dan institusi-institusi yang lebih besar, (Thoha, 2014).

Ajzen 1991), dalam teorinya yang bernama Theory of Planned Behavior (TPB) (teori tindakan yang beralasan), teori ini menyatakan ada asumsi bahwa manusia adalah makhluk yang rasional dan menggunakan informasi-informasi yang mungkin baginya secara sistematis. Theory of Planned Behavior mampu memprediksi perilaku-perilaku individu yang sepenuhnya tidak di bawah kendali individu tersebut, selanjutnya juga dinyatakan bahwa teori ini menjadi penentu perilaku seseorang dalam intensi untuk berperilaku. Komponen utama pembentuk TPB adalah sikap, norma subjektif, dan persepsi control perilaku. Achmat 2010), menyatakan bahwa sikap individu terhadap perilaku terdiri atas kepercayaan pada suatu perilaku, evaluasi atas hasil perilaku, kepercayaan-kepercayaan normatif, norma subjektif dan motivasi untuk patuh.

Sofyandi \& Garniwa (2007), menjelaskan unsur-unsur yang perlu dipertimbangkan dalam perilaku organisasi dan perilaku individu adalah :

a) Aspek psikologis tindakan manusia itu sendiri sebagai hasil studi psikologis

b) Adanya bagian lain yang diakui cukup relevan bagi usaha mempelajari tindakan manusia dalam organisasi

c) Perilaku organisasi sebagai suatu disiplin, mengakui bahwa individu dipengaruhi oleh bagaimana organisasi diatur dan siapa yang mengawasi mereka. Oleh sebab itu, struktur organisasi memegang peranan penting dalam membahas perilaku organisasi Walau disadari akan adanya keunikan masing-masing individu, perilaku organisasi lebih banyak menekankan pada tuntutan manajer bagi tercapainya tujuan organisasi secara keseluruhan

d) Perilaku organisasi menggunakan metode ilmiah untuk mengatasi masalah-masalah manajerial.

Penelitian terkait Perilaku Individu juga banyak dilakukan oleh peneliti terdahulu seperti:(Adilansyah et al., 2018; Amalia \& Nugroho, 2020; Ana \& Pratiwi, 2019; Arsaman \& Sugiyanto, 2020; Ernawati \& Tumanggor, 2020; Inayatuddiniyah, 2019; Indriani \& Komariah, 2020; KURNIASARI, 2020; Naibaho, 2019; Noor, 2018; Nurqadarsi, 2019; Pahlawan \& Prabowo, 2020; Permatasari, 2020; Pratiwi et al., 2020; Rahim et al., 2020; RATIH, 2020; Sakti \& Sukartini, 2020; SAKTI, 2020; A. R. Sari et al., 2020; SUTRISNA, 2019; Syahputra, 2019; Tuhagana, 2019; Wardhani, 2020; Widiyanto, 2018; Yandri et al., 2019).

\section{METODE PENULISAN}

Metode penulisan artikel ilmiah ini adalah dengan metode kualitatif dan studi literatur atau library research. Mengkaji dan menelaah buku-buku literatur sesuai dengan teori yang di bahas khusunya di lingkup Manajemen Sumberdaya Manusia (MSDM). Disamping itu menganalisis artikel-artikel ilmiah yang bereputasi dan juga artikel ilmiah dari jurnal yang belum bereputasi. Semua artikel ilmiah yang di citasi bersumber dari Mendeley dan Scholar Google. Dalam penelitian kualitatif, kajian pustaka harus digunakan secara konsisten dengan asumsi-asumsi metodologis. Artinya harus digunakan secara induktif sehingga tidak mengarahkan pertanyaan-pertanyaan yang diajukan oleh peneliti. Salah satu alasan utama untuk melakukan penelitian kualitatif yaitu bahwa penelitian tersebut bersifat eksploratif, $(\mathrm{H}$. 
Ali \& Limakrisna, 2013). Pada tahap selanjutnya akan dibahas secara mendalam pada bagian yang berjudul "Pustaka Terkait" (Related literature) atau kajian pustaka("Review of literature"), sebagai dasar perumusan hipotesis dan dan pada tahap akhir akan kdua literatur ini akan menjadi dasar dalam melakukan perbandingan dengan hasil atau temuan-temuan yang terungkap dalam penelitian, (H. Ali \& Limakrisna, 2013).

\section{PEMBAHASAN}

Berdasarkan rumusan masalah dan kajian literature review, maka pembahsan artikel ini adalah sebagai berikut:

\section{1) Karakteristik Individu berpengaruh terhadap Kinerja Dosen}

Karakteristik individu adalah ciri khas atau sifat khusus yang dimiliki karyawan yang dapat menjadikan dirinya memiliki kemampuan yang berbeda dengan karyawan yang lainnya untuk mempertahankan dan memperbaiki kinerjanya, (Aktarina, 2019). Dengan demikian dapat dinyatakan bahwa seluruh atribut atau nilai diri yang melekat dalam suatu individu menjadi faktor yang mampu untuk mengindikasi pencapaian suatu harapan atau terlaksananya suatu pekerjaan dengan baik yang akhirnya menunjukkan prestasi tidaknya seorang individu dalam bekerja. Penelitian terdahulu yang meneliti hubungan dan pengaruh karakteristik individu terhadap kinerja pegawai adalah penelitian oleh (Abadylla, 2015; C. Anwar, 2014a; Astuti, 2017; Handayati, 2016; Y. Hidayat, 2018; Nurisman et al., 2017), menemukan bahwa karakteristik yang dimiliki pegawai berpengaruhi signifikan terhadap pencapaian kinerja pegawai.

Peneliti terbaru terkait dengan karakteristik individu terhadap kinerja pegawai temuan mereka juga mengindikasikan bahwa atribut karakteristik diri yang dimiliki setiap pegawai menentukan terwujudnya kinerja pegawai dalam bekerja, seperti penelitian (Agustina et al., 2019; ANANDA, 2020; Ariani et al., 2020; M. B. Arifin \& Pandowo, 2020; Damuri et al., 2019; Fauziah, 2019; Hasanah, 2018; Islamiyah, 2019; Janati, 2019; KARYONO, 2020; PRATAMA, 2020; Primadani \& Sumiati, 2019; Puspita et al., 2020; Rahmawardani \& ..., 2019; Ratnasari et al., 2020; Saliding et al., 2019; Setyaningsih, 2019; Suban et al., 2020; Sukmawati et al., 2020; Syamsuddin, 2020; Tambingon et al., 2019; K. E. Wibowo \& Wujoso, 2020).

Perbedaan karakteristik individu dapat menjelaskan penyebab berbedanya kinerja karyawan yang satu dengan lain. Baik buruknya karakteristik individu karyawan tergantung bagaimana mereka mengaplikasikannya, (Umar, 2019). Karakteristik individu adalah karakter yang dimiliki oleh setiap orang yang berbeda antara orang yang satu dengan yang lainnya, (Agustina et al., 2019). Temuan diatas memperlihatkan bahwa kajian tentang hubungan dan pengaruh karakteristik individu dengan kinerja pegawai relatif sudah banyak dilakukan.

\section{2) Budaya kerja berpengaruh terhadap Kinerja dosen}

Budaya kerja adalah faktor penting, karena mampu merubah sikap dan prilaku individuindividu yang menjadi sumber daya manusia untuk mencapai produktivitas kerja yang lebih tinggi dalam menghadapi tantangan masa depan. Schein (2010), menyatakan juga budaya sebagai suatu pola asumsi dasar bersama yang dipelajari kelompok tertentu untuk mengatasi masalah adaptasi eksternal dan integrasi internal. Penelitian yang relevan dengan budaya kerja yang dilakukan oleh (F. Amalia, 2015; Basri, 2017; F. Kurniawan, 2019; Nirwana et al., 2018; 
Prasetyo \& Nugraheni, 2020; PRASETYO, 2019; Rizqina et al., 2017) menemukan terdapat hubungan dan pengaruh yang signifikan dalam mempengaruhi capaian kinerja pegawai atau karyawan. Ini mengindikasikan bahwa budaya adalah bagian komitmen dari semua individu yang ada dalam suatu organisasi terhadap nilai-nilai yang dianut, mampu menjadi faktor yang mendukung dan mengarahkan individu tersebut dalam mencapai prestasi atau kinerjanya.

Penelitian lain yang juga menemukan hasil yang relevan dengan penelitian di atas adalah penelitian (A. Hidayat, 2017; Indriapati et al., 2020; ISNAINI, 2019; Jayanti \& Nazwirman, 2020; Lutfiyah et al., 2020; Nur \& Syam, 2020; Nurdiansyah, 2017; Utomo, 2020; Wakhyuni \& Dalimunthe, 2020; Yulianty, 2016), dimana terdapat bukti yang sahih dan menyakinkan bahwa budaya kerja adalah faktor yang penting dan menentukan pencapaian kinerja pegawai. Produktifitas kerja yang tinggi dalam suatu organisasi sangat dipengaruhi pola dan mekanisme kerja. makin efektif dan efisien pelaksanaan tugas suatu organisasi makin semakin besar potensi untuk menghasilkan produktifitas kerja yang tinggi, (Indraputra \& Sutrisna, 2013). Penelitian yang dilakukan D. S. Widodo (2017), menemukan bahwa budaya kerja berpengaruh positif dan signifikan terhadap kinerja pegawai. Sinha et al., (2010), menyatakan bahwa tipe budaya kerja kewirausahaan merupakan prediktor yang kuat terhadap kinerja. Berdasarkan penjelasan di atas dapat disimpulkan bahwa kajian tentang hubungan dan pengaruh budaya kerja dengan kinerja pegawai relatif sudah banyak dilakukan atau diteliti.

\section{3) Perilaku individu berpengaruh terhadap Kinerja Dosen}

Menurut Perilaku Adair et al., (2016), merupakan keseluruhan atau totalitas kegiatan akibat belajar dari pengalaman sebelumnya dan dipelajari melalui proses penguatan dan pengkondisian, (Adair et al., 2016). Dengan kata lain Perilaku individu adalah sebagai suatu fungsi dari interaksi antara individu dengan lingkungannya. Individu membawa tatanan dalam organisasi berupa kemampuan, kepercayaan pribadi, pengharapan, kebutuhan, dan pengalaman masa lainnya. Temuan penelitian yang dilakukan oleh (Batu \& Ratnasari, 2014; Tanasal \& Kojo, 2016), menunjukkan bahwa perilaku individu berpengaruh signifikan terhadap kinerja pegawai dalam bekerja. Begitu juga temuan penelitian yang dilakukan oleh (KURNIASARI, 2020; ROMADHONA, 2019; Wardhani, 2020), juga menemukan bahwa perilaku individu terbukti mampu mendukung pelaksanaan pekerjaan dan pencapaian prestasi kerja pegawai.

Tanasal \& Kojo (2016), menyatakan bahwa Perilaku individu sebuah sikap/tingkah laku seorang manusia dalam organisasi sebagai ungkapan dari kepribadian, persepsi dan sikap jiwanya, yang bisa berpengaruh terhadap prestasi (kinerja) dirinya dan organisasinya. Sebagaimana yang diungkapkan oleh Thoha (2014), perilaku individu dan hubungan dengan dengan organisasi merupakan sebagai suatu sistem studi dari sifat organisasi seperti misalnya bagaimana organisasi dimulai, tumbuh dan berkembang dan bagaimana pengaruh terhadap anggota-anggota sebagai individu, kelompok-kelompok pemilih, organisasi-organisasi lainnya dan institusi-institusi yang lebih besar. Hasil ini memperlihatkan, masih relatif belum banyak peneliti yang mengkaji hubungan dan pengaruh perilaku individu dengan kinerja pegawai.

\section{4) Organizational citizenship behavior berpengaruh terhadap Kinerja Dosen}


Perilaku ektra peran atau organizational citizenship behavior merupakan perilaku dan sikap kerja yang dapat menguntungkan bagi organisasi dalam memaksimalkan pencapaian tujuan dan kinerja organisasi termasuk kinerja pegawai itu sendiri, (R B Putra, 2016), (R B Putra, 2018). Jika hal ini mampu dikelola oleh organisasi secara baik, dengan memberikan perhatian dan dukungan yang maksimal baik dalam hal peningkatan kesejahteraan pegawai maupun pemberian dukungan pengembangan karir maka hal ini akan dapat mengefektifkan semua pencapaian tujuan organisasi kearah yang lebih baik lagi.

Penelitian terkait organizational citizenship behavior terhadap kinerja karyawan atau pegawai telah banyak dilakukan seperti, penelitian yang dilakukan oleh (Arianto, 2017; Halim \& Dewi, 2018; Lestari \& Ghaby, 2018; Pristiwati \& Suharyono, 2018; Rahayu, 2017b; Suzana, 2017), rata-rata secara keseluruhan mereka menembukan bahwa organizational citizenship behavior memiliki dampak yang positif terhadap kinerja karyawan dan dapat membantu organisasi dalam mencapai tujuannya. Penelitian lain baru-baru ini juga menemukan bahwa organizational citizenship behavior menjadi faktor yang mendukung dan mempengaruhi pencapaian kinerja karyawan dalam bekerja, seperti penelitian (Agustin \& Sriwidodo, 2017; Gautama, 2020; Hidayah, 2019; Ilmih, 2019; Marlina et al., 2020; Mattalatta, 2019; Nurusyifa, 2019; Sanjaya, 2020; Tiara, 2020; UTOMO \& Wajdi, 2019; Wahib, 2019; A. Widodo et al., 2019). Hasil ini menunjukkan bahwa OCB adalah faktor yang penting dan menentukan pencapaian kinerja karyawan baik secara langsung maupun secara tidak langsung sebagai variabel intervening atau mediasi.

\section{5) Karakteristik Individu berpengaruh terhadap Organizational citizenship behavior}

S. P. Robbins, n.d. (2015), "karakteristik individu adalah kepribadian yang membentuk preferensi atau imbalan, gaya komunikasi, reaksi kepada pimpinan, gaya negoisasi yang mempengaruhi organisasi". Hasil penelitian yang dilakukan oleh (C. Anwar, 2014a; Handayani, 2017; Haryanti, 2020; Januar, 2020; Mukoffi, 2018; N M Saragih, 2020; Simanjuntak et al., 2020; Wibawa et al., 2017) menunjukan bahwa karakteristik individu memiliki kontribusi dalam menentukan perilaku ekstra peran atau organizational citizenship behavior individu dalam memaksimalkan pelaksanaan pekerjaannya.

Nahar Maganda Saragih (2020), prilaku OCB dapat dikembangkan dalam tiap tiap individu melalui proses pengembangan yang diterimanya. Oleh karena itu OCB dapat tumbuh bukan hanya berdasarkan perilaku individu saja, melainkan dari proses penerimaan individu tersebut didalam organisasinya. Organizational citizenship behavior adalah tindakan terpuji dari anggota organisasi. Sikap OCB ini diimplementasikan dalam bentuk tindakan yang dilakukan secara ikhlas dan tanpa pamrih untuk secara sukarela memberikan kinerja terbaiknya guna memajukan organisasi, (Nahar Maganda Saragih, 2020). Dari penjelasan di atas dapat disimpul bahwa masih relatif belum banyak peneliti yang mengkaji hubungan dan pengaruh karakteristik individu dengan Organizational citizenship behavior.

\section{Budaya kerja berpengaruh terhadap Organizational citizenship behavior}

Budaya kerja adalah suatu falsafah yang didasari oleh pandangan hidup sebagai nilainilai yang menjadi sifat, kebiasaan dan kekuatan pendorong, membudaya dalam kehidupan 
suatu kelompok masyarakat atau organisasi, kemudian tercermin dari sikap menjadi perilaku, kepercayaan, cita-cita, pendapat dan tindakan yang terwujud sebagai "kerja" atau "bekerja" (Triguno, 1995). Beberapa temuan penelitian yang menjelaskan terdapat pengaruh yang signifikan budaya organisasi terhadap Organizational citizenship behavior adalah penelitian (Alfani \& Hadini, 2017; Karim, 2010; Mahayasa et al., 2018; Rahayu, 2017a; SUPARDI et al., 2020). Temuan ini menunjukkan bahwa budaya kerja menjadi motivasi atau motif bagi seorang individu untuk mau berperilaku ekstra peran atau OCB dalam melaksanakan pekerjaannnya.

Temuan lain yang juga sejalan dengan hasil penelitian di atas adalah penelitian ( HUSAINI, 2019; Kusumawardani \& ..., 2018; Mahmudi \& Surjanti, 2020; Muharif, 2016; Prihanto \& Prayekti, 2018; Qhistina, 2020; Rahmawati \& Prasetya, 2017). Siders et.al. (2001) menyatakan bahwa Organizational Citizenship Behavior (OCB) dipengaruhi oleh dua faktor utama, yaitu faktor yang berasal dari dalam diri karyawan (internal) dan faktor yang berasal dari luar karyawan (eksternal), faktor yang berasal dari dalam diri karyawan misalnya moral, rasa puas, sikap positif, dan faktor yang berasal dari luar karyawan misalnya sistem manajemen, sistem kepeminpinan, dan budaya organisasi. Berdasarkan paparan di atas dapat disimpulkan $\mathrm{n}$ bahwa kajian tentang hubungan dan pengaruh budaya kerja dengan organizational citizenship behavior relatif sudah banyak diteliti.

\section{Perilaku individu berpengaruh terhadap Organizational citizenship behavior}

Perilaku individu merupakan pola perilaku berupa sikap dan tindakan yang ditampilkan oleh pegawai atau karyawan dalam melaksanakan aktifitas pekerjaannya. Penelitian yang mengkaji pengaruh perilaku terhadap organizational citizenship behavior secara spesifik masih belum banyak diteliti, namun hanya meneliti perilaku individu dalam bentuk faktor kepribadian self eficacy dan komitmen terhadap organizational citizenship behavior seperti yang dilakukan oleh, (Barlian, 2016; Darto, 2014; Fahmi, 2017; Soepono \& Srimulyani, 2015). Penelitian lain yang juga meneliti ini seperti, (Chhetri, 2014; Debusscher, 2016; Osman, 2015; Paille, 2009; Pedaran, 2012; Ravichandran, 2007; Valliappan, 2015). Dari literatur penelitian terdahulu, ternyata memang belum banyak literatur penilit yang mengangkat masalah hubungan dan pengaruh secara spesifik antara perilaku individu secara umum dengan organizational citizenship behavior. Hasil ini dapat menjadi gab riset atau kesenjangan dari penelitian untuk penelitian berikutnya untuk mengkaji hubungan dan pengaruh antara perilaku individu dengan organizational citizenship behavior.

\section{Karakteristik Individu berpengaruh terhadap Kinerja Dosen melalui Organizational citizenship behavior}

Penjelasan terhadap pengaruh tidak langsung (indirect effect) dari pengaruh karakteristik individu terhadap kinerja pegawai melalui variabel organizational citizenship behavior (OCB), masih relatif belum banyak peneliti yang mengkaji ini seperti penelitian yang dilakukan oleh (C. Anwar, 2014a) menemukan bahwa terdapat pengaruh yang signifikan pengaruh karakteristik terhadap kinerja pegawai melalui variabel organizational citizenship behavior (OCB). Dalam artian pengaruh pengaruh karakteristik terhadap kinerja pegawai akan lebih maksimal jika semua pegawai mampu bertindak dan menerapkan sikap dan perilaku kerja atas dasar organizational citizenship behavior (OCB) dalam mendukung pekerjaan mereka. 
Sedangkan hasil penelitian terkait hipotesis ini dari pengaruh karakteristik terhadap kinerja pegawai melalui variabel organizational citizenship behavior (OCB), hanya menjadikan variabel intervening berupa variabel lain seperti motivasi, kepuasan kerja, komitmen, disiplin kerja, dan kompensasi, seperti penelitian yang dilakukan oleh, (Ananda \& Sunuharyo, 2018; Bustomi et al., 2017; Dianta, 2020; Firmansyah, 2020; Kridharta \& Rusdianti, 2017; Lishandy, 2018; Nurisman et al., 2017; PRATAMA, 2020; Primadani \& Sumiati, 2019; Putri \& ISGIYARTA, 2015; Ramdhani, 2020; Ramdhani \& Sridadi, 2019; Susanti, 2016). Hasil ini menunjukkan ada peluang riset gap untuk diteliti dan dikaji pengaruh karakteristik terhadap kinerja pegawai melalui variabel organizational citizenship behavior.

\section{Budaya kerja berpengaruh terhadap Kinerja Dosen melalui Organizational citizenship behavior}

Penilaian pengaruh tidak langsung (indirect effect) untuk hipotesis ini adalah pengaruh budaya kerja terhadap kinerja pegawai melalui variabel organizational citizenship behavior (OCB), atau untuk menilai sejauhmana kontribusi organizational citizenship behavior (OCB) dalam memaksimalkan pengaruh budaya kerja terhadap kinerja dosen. Penelitian yang dilakukan (Hidayanti, 2014; Lovihan, 2014; Maesaroh et al., 2020; Nurcahyo, 2018; S. A. Sari, 2016; Supriyanto, 2017; Syaifudin, 2017; Trimisat, 2020; Tupamahu, 2018; Wahib, 2019; Wildan \& Safrizal, 2017). Temuan mereka menemukan bahwa organizational citizenship behavior (OCB) mampu memberikan kontribusi yang signifikan dalam memperkuat pengaruh budaya dalam meningkatkan kinerja pegawai.

Penelitian lain yang juga relevan dengan penelitian ini adalah hasil penelitian yang dilakukan oleh (Aslamiah, 2020; Taufiqurrohman, 2020; Widyaningrum, 2020), temuan mereka juga menyimpulkan bahwa budaya organisasi berpengaruh signifikan terhadap kinerja pegawai melalui OCB. Dengan demikian dapat dinyatakan bahwa penelitian terkait hubungan ketiga variabel ini juga telah banyak ditelit dan dikaji oleh para peneliti.

\section{Perilaku individu berpengaruh terhadap Kinerja Dosen melalui Organizational citizenship behavior}

Selanjutnya hipotesis pengaruh tidak langsung atau indirect effek dari perilaku individu terhadap kinerja dosen melalui organizational citizenship behavior (OCB). Penelitian terdahulu terkait dengan hipotesis ini, masih relatif sedikit literatur yang membahas ini. Namun lebih banyak membahas pengaruh langsung perilaku individu terhadap kinerja pegawai seperti penelitian (Batu \& Ratnasari, 2014; Haeriah, 2012; KURNIASARI, 2020; Pancaria, 2014; RO’UF, 2018; SUPARMAN, 2014; Tanasal \& Kojo, 2016; Wardhani, 2020) dimana temuan mereka secara keseluruhan menunjukkan terdapat pengaruh yang signifikan pengaruh perilaku individu terhadap kinerja karyawan.

Penelitian lain yang juga mengkaji hubungan ketiga variabel namun menggunakan variabel bebas yang berbeda yang dimediasi dengan variabel organizational citizenship behavior (OCB) adalah penelitian (Haryanti, 2020), (Agustiningrum, 2016; Anggraini, 2017; F. F. Arifin, 2019; Diantono, 2015; Isnaini et al., 2018; Junawar et al., n.d.; R. A. Kurniawan et al., 2019; Lovihan, 2014; Muhdar, 2014; Nurcahyo, 2018; Pratama, 2016; Wahib, 2019; Wediyasari, n.d.). Dari penjelasan terdapat riset gap bagi peneliti yang akan datang untuk dapat 
mengkaji dan menganalisi hubungan dan pengaruh pengaruh perilaku individu terhadap kinerja pegawai melalui variabel organizational citizenship behavior (OCB) dimasa mendatang.

Berdasarkan uraian hipotesis dapat disimpulkan masih terdapat peluang untuk mengkaji kinerja pegawai dalam suatu penelitian lebih lanjut dengan mempertimbangkan beberapa faktor yang relatif belum banyak dikaji dan diteliti. Untuk itu dilakukan Prariset : Survey terkait faktor-faktor yang dominan untuk mengidentifikasi Organizational citizenship behavior (Y1) dan Kinerja Pegawai (Y2). Di antara banyak faktor yang dapat digunakan untuk mengindentifikasi Organizational citizenship behavior (Y1) dan Kinerja Pegawai (Y2). Berikut 10 faktor atau variabel yang mempengaruhi mempengaruhi Organizational citizenship behavior (Y1) dan Kinerja Pegawai (Y2) dalam organisasi atau perusahaan. Berikut hasil pra riset yang dilakukan dengan menggunakan skala likert 5 yaitu: 1). Tidak berpengaruh; 2). Kurang berpengaruh; 3). Cukup berpengaruh; 4). Berperngaruh; dan 5). Sangat berpengaruh. Survey kepada 20 orang dengan 10 pertanyaan yang meliputi:

Tabel-1: Rekap hasil pra riset:

\begin{tabular}{|c|c|c|c|}
\hline No & $\begin{array}{c}\text { Pertanyaan: Faktor-faktor } \\
\text { yang mempengaruhi Y: }\end{array}$ & Total & Rank \\
\hline 1 & Kepuasan Kerja & 74 & 5 \\
\hline 2 & Karakteristik Individu (B) & $\mathbf{8 5}$ & $\mathbf{1}$ \\
\hline 3 & Motivasi Kerja & 63 & 8 \\
\hline 4 & Dbudaya Kerja (D) & $\mathbf{8 3}$ & $\mathbf{2}$ \\
\hline 5 & Perilaku Individu (E) & $\mathbf{8 0}$ & $\mathbf{3}$ \\
\hline 6 & Kepemimpinan transformasional & 77 & 4 \\
\hline 7 & Disiplin kerja & 58 & 9 \\
\hline 8 & Stres Kerja & 49 & 10 \\
\hline 9 & Lingkungan Kerja & 65 & 7 \\
\hline 10 & Kompensasi & 69 & 6 \\
\hline
\end{tabular}

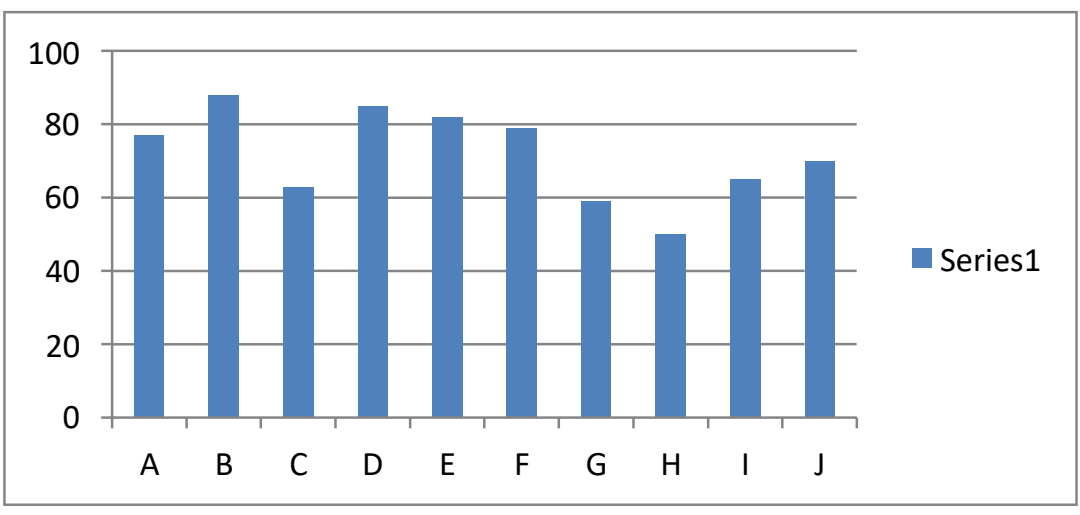

Figure-1: Grafik Hasil Pra Survey

Dari hasil pra riset terindentifikasi sebanak 3 faktor yang paling dominan yang mempengaruhi variabel Y1 dan Y2 yaitu :

1. Skor tertinggi $1=$ faktor $B$, sebagai variabel Karakteristik individu $\left(X_{1}\right)$

2. Skor tertinggi 2 faktor $\mathrm{D}$, sebagai variabel Budaya kerja $\left(\mathrm{X}_{2}\right)$ 
3. Skor tertinggi 3 = faktor $\mathrm{E}$, sebagai variabel Perilaku individu $\left(\mathrm{X}_{3}\right)$

\section{Conceptual Framework}

Atas dasar kajian teori dan penelitian terdahulu terkait hubungan antar variable, maka model atau Conceptual Framework yang relevan untuk membangun hipotesis penelitian adalah sebagai berikut:

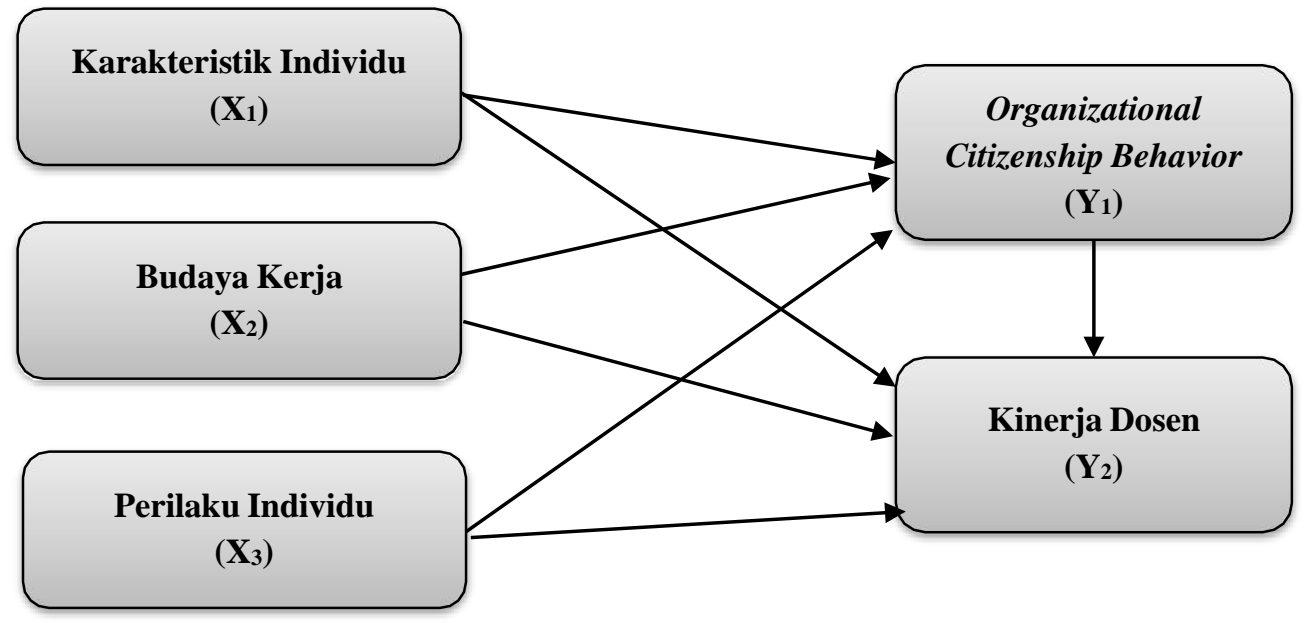

\section{Gambar 3: Conceptual Framework}

Pada conceptual framework di atas diketahui 3 variabel eksogen aitu Karakteristik individu $\left(\mathrm{X}_{1}\right)$, Budaya kerja $\left(\mathrm{X}_{2}\right)$ dan Perilaku individu $\left(\mathrm{X}_{3}\right)$ yang memiliki hubungan dan engaruh terhadap Organizational Citizenship Behavior $\left(\mathrm{Y}_{1}\right)$ dan Kinerja Dosen ( $\left.\mathrm{Y}_{2}\right)$ baik secara langsung dan maupun tidak langsung. Namun dari model di atas masih terdapat faktor yang juga mampu mempengaruhi dan mengindentifikasi kinerja pegawai atau dosen baik secara langsung maupun tidak langsung, seperti :

1) Kepemimpinan transformasional (X $\left.\mathbf{X}_{4}\right)$ : (Limakrisna et al., 2016), (Bastari et al., 2020), (K. Anwar et al., 2020), (H. Ali et al., 2016), (Djoko Setyo Widodo, P. Eddy Sanusi Silitonga, 2017), (Chauhan et al., 2019), (Elmi et al., 2016), (Limakrisna et al., 2016), (Bastari et al., 2020), (K. Anwar et al., 2020), (H. Ali et al., 2016), (Djoko Setyo Widodo, P. Eddy Sanusi Silitonga, 2017), (Chauhan et al., 2019), (Elmi et al., 2016)..

2) Kepuasan Kerja (X5): (Harini et al., 2020), (Masydzulhak et al., 2016), and (Silitonga et al., 2017), (Hewagama, 2019; Isaac, 2017; Mullen, 2017; Sharma, 2016), (Amin, 2017; Bowling, 2015; Fabi, 2015; Gangai, 2015; Hewagama, 2019; Jung, 2015; Kampkötter, 2017; Luna-Arocas, 2015; Meneghel, 2016; Menguc, 2016; Mulki, 2015; Pan, 2015; Rodríguez, 2016; Sony, 2016; Tarcan, 2017; Wagenaar, 2015).

3) Kompensasi (X6): (Riyanto, Pratomo, et al., 2017), (Purba et al., 2017), (Bol, 2015; Chrisman, 2017; Gartenberg, 2017; Gelard, 2016; Gittleman, 2015; Keller, 2018; Lamalewa, 2018; McDonnell, 2016; Moghimi, 2017; Newton, 2015; Schwatka, 2017; Tang, 2018; Torre, 2015; Yan, 2016)

\section{KESIMPULAN DAN SARAN}

\section{Kesimpulan}


Berdasarkan hasil dan pembahasan, maka dapat disimpulkan untuk membangun suatu hipoteis guna untuk riset selanjutnya seperti di bawah ini:

1) Karakteristik individu berpengaruh terhadap kinerja dosen?

2) Budaya kerja berpengaruh terhadap kinerja dosen?

3) Perilaku individu berpengaruh terhadap kinerja dosen?

4) Organizational citizenship behavior berpengaruh terhadap kinerja dosen?

5) Karakteristik individu berpengaruh terhadap organizational citizenship behavior?

6) Budaya kerja berpengaruh terhadap organizational citizenship behavior?

7) Perilaku individu berpengaruh terhadap organizational citizenship behavior?

8) Karakteristik individu berpengaruh terhadap kinerja dosen melalui organizational citizenship behavior?

9) Budaya kerja berpengaruh terhadap kinerja dosen melalui organizational citizenship behavior?

10) Perilaku individu berpengaruh terhadap kinerja dosen melalui organizational citizenship behavior?

\section{Saran}

Berdasarkan Kesimpulan di atas, dapat saran bahwa masih banyak factor lain yang mempengaruhi Kinerja dosen dan organizational citizenship behavior pada semua tipe dan level organisasi, oleh karena itu masih di perlukan kajian yang lebih lanjut untuk melengkapi factor-faktor lain apa sajakah yang dapat memepengaruhi kinerja dan perilaku ekstra peran (OCB) dimasa yang akan datang.

\section{DAFTAR PUSTAKA}

Abadylla, H. I. (2015). Pengaruh Lingkungan Kerja Karakteristik Individu dan Motivasi Terhadap Kinerja Karyawan (Studi Pada Perguruan Tinggi Swasta IKIP PRGI Jember). Jurnal Ilmiah Mahasiswa FEB. https://jimfeb.ub.ac.id/index.php/jimfeb/article/view/2341

Achmat, Z. (2010). Theory of planned behavior, masihkah relevan. Diambil Dari: Http://Zakarija. Staff. Umm. Ac. Id/Files/20, 10, 12.

Adair, J. M., Richardson, E., \& Garway, W. (2016). Abbot, G.(1737) Cases of Impotency and Divorce, as Debated in England, 3 vols (London: E. Curll), I. Adair, JM (1786)' On Fashionable Diseases', Medical Cautions for the Consideration of Invalids; Those Especially Who Resort to Bath: Containing Essays on F. Palgrave Studies in Literature, Science and Medicine, 247.

Adilansyah, N. N., Annisya, A., \& ... (2018). Kajian Perubahan Perilaku Individu Biasa Menjadi Teroris.

Jurnal

http://komunikasistisip.ejournal.web.id/index.php/komunikasistisip/article/view/160

Aditianti, A., Prihatini, S., \& Hermina, H. (2016). Pengetahuan, Sikap dan Perilaku Individu Tentang Makanan Beraneka Ragam sebagai Salah Satu Indikator Keluarga Sadar Gizi (KADARZI). In Indonesian Bulletin of Health .... core.ac.uk. https://core.ac.uk/download/pdf/233106652.pdf

Adiwijayanti, B. R. (2015). Hubungan Karakteristik Individu Terhadap Kadar Timbal Dalam Darah Dan Dampaknya Pada Kadar Hemoglobin Pekerja Percetakan Di Kawasan Megamall Ciputat .... repository.uinjkt.ac.id. http://repository.uinjkt.ac.id/dspace/handle/123456789/29454

Afuan, M., Putra, R. B., \& Kumbara, V. B. (2020). PENGARUH PENGALAMAN KERJA DAN BEBAN KERJA TERHADAP PRESTASI KERJA MELALUI ORGANIZATIONAL CITIZENSHIP BEHAVIOR (OCB) PEGAWAI .... Jurnal Ilmu Manajemen Terapan. https://dinastirev.org/JIMT/article/view/327

Agustin, E. Y., \& Sriwidodo, U. (2017). Pengaruh Kecerdasan Emosional, Komitmen Organisasi, dan 
Organizational Citizenship Behavior Terhadap Kinerja Karyawan PT Metropolitan Retailmart Solo .... In Jurnal Ekonomi dan Kewirausahaan. ejurnal.unisri.ac.id. http://ejurnal.unisri.ac.id/index.php/Ekonomi/article/download/1642/1446

Ali, H., \& Limakrisna, N. (2013). Metodologi Penelitian (Petunjuk Praktis untuk Pemecahan Masalah Bisnis, Penyusunan Skripsi, Tesis, dan Disertasi). Deeppublish: Yogyakarta.

Ali, H., Mukhtar, \& Sofwan. (2016). Work ethos and effectiveness of management transformative leadership boarding school in the Jambi Province. International Journal of Applied Business and Economic Research.

Ali, M. (2018). The mediating role of the employee relations climate in the relationship between strategic HRM and organizational performance in Chinese banks. Journal of Innovation and Knowledge, 3(3), 115-122. https://doi.org/10.1016/j.jik.2016.12.003

Alsheikh, G. (2019). Effect of behavioral variables on organizational citizenship behavior (OCB), with job satisfaction as moderating among Jordanian five-star hotels: A pilot study. International Journal of Ethics and Systems, 35(2), 272-283. https://doi.org/10.1108/IJOES-01-2019-0001

Anwar, C. (2014a). ... Karakteristik Individu, Budaya Organisasi, dan Motivasi Kerja terhadap Kinerja Karyawan melalui Organizational Citizenship Behavior (OCB) pada Karyawan Bank .... repository.unej.ac.id. https://repository.unej.ac.id/handle/123456789/58030

Anwar, C. (2014b). Pengaruh Karakteristik Individu, Budaya Organisasi, dan Motivasi Kerja terhadap Kinerja Karyawan melalui Organizational Citizenship Behavior (OCB) pada .... repository.unej.ac.id. https://repository.unej.ac.id/handle/123456789/58030

Anwar, K., Muspawi, M., Sakdiyah, S. I., \& Ali, H. (2020). The effect of principal's leadership style on teachers' discipline. Talent Development and Excellence.

Ariani, R., Suseno, Y. D., \& Sutarno, S. (2020). ANALISIS PENGARUH PENEMPATAN KARYAWAN, KARAKTERISTIK INDIVIDU, DAN STRES KERJA TERHADAP KINERJA

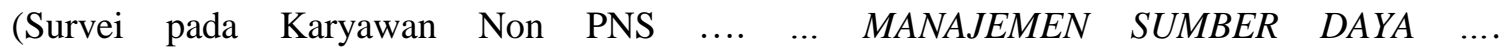
http://ejurnal.unisri.ac.id/index.php/Manajemen/article/view/3633

Arianto, D. (2017). Pengaruh Kepuasan Kerja Terhadap Kinerja Karyawan Melalui Organizational Citizenship Behavior Sebagai Variabel Intervening (Studi Pada Staff Pt Kepuh .... Jurnal Ilmu Manajemen (JIM). https://jurnalmahasiswa.unesa.ac.id/index.php/jim/article/view/20071

Arifin, F. F. (2019). Efek Mediasi Organizational Citizenship Behavior diantara Kecerdasan Emosional dan Kecerdasan Spiritual terhadap Kinerja Tenaga Kependidikan Universitas .... Jurnal Ilmiah Administrasi Publik. https://jiap.ub.ac.id/index.php/jiap/article/view/927

Arifin, M. B., \& Pandowo, M. H. C. (2020). PERAN LINGKUNGAN KERJA, KEMAMPUAN KERJA, DAN KARAKTERISTIK INDIVIDU TERHADAP KINERJA KARYAWAN PADA PT. BUANA FINANCE TBK ... Jurnal EMBA: Jurnal Riset $\ldots$ https://ejournal.unsrat.ac.id/index.php/emba/article/view/30437

Arifudin, O., \& Rusmana, F. D. (2020). PENGARUH LINGKUNGAN KERJA DAN KARAKTERISTIK INDIVIDU TERHADAP KINERJA PEGAWAI BANK BRI SYARIAH KABUPATEN SUBANG. Islamic Banking: Jurnal ... https://ejournal.stebisigm.ac.id/index.php/isbank/article/view/134

Arsaman, A., \& Sugiyanto, S. (2020). PENGARUH PERILAKU INDIVIDU DAN DISIPLIN KERJA TERHADAP PRESTASI KERJA KARYAWAN PT. ADMINISTRASI MEDIKA JAKARTA. PROCEEDINGS

http://www.openjournal.unpam.ac.id/index.php/Proceedings/article/view/7057

Aslamiah, A. (2020). Hubungan Budaya Kerja, Kecerdasan Emosional dan Porganizational Citizenship Behavior (OCB) Terhadap Kinerja Mengajar Guru SD Kecamatan .... eprints.ulm.ac.id. http://eprints.ulm.ac.id/5224/1/penelitian 1.pdf

Astakhova, M. (2015). The Curvilinear Relationship between Work Passion and Organizational Citizenship Behavior. Journal of Business Ethics, 130(2), 361-374. https://doi.org/10.1007/s10551-014-2233-5

Asthenu, J. R. (2013). ... KOMITMEN ORGANISASIONAL DAN SIKAP PADA BUDAYA ORGANISASI TERHADAP ORGANIZATIONAL CITIZENSHIP BEHAVIOR (OCB) PEGAWAI DINAS $\quad \ldots .$. ARTHAVIDYA. 
http://arthavidya.wisnuwardhana.ac.id/index.php/arthavidya/article/view/82

Astuti, T. B. (2017). Analisis Lingkungan Kerja, Karakteristik Individu dan Motivasi Pengaruhnya Terhadap Kinerja Karyawan (Studi pada PT. Swasta STIE Malangkucecwara Malang). Akutansi Bisnis \& Manajemen (ABM). http://journal.stie-mce.ac.id/index.php/jabm/article/view/146

Astutik, M., \& Priantono, S. (2020). Pengaruh Karakteristik Pekerjaan Terhadap Kinerja Karyawan dan Kepuasan Kerja Dengan Variabel Moderator Budaya Kerja Pada Badan Keswadayaan .... Jurnal Manajemen. http://ejournal.atmajaya.ac.id/index.php/JM/article/view/1296

Bastari, A., -, H., \& Ali, H. (2020). DETERMINANT SERVICE PERFORMANCE THROUGH MOTIVATION ANALYSIS AND TRANSFORMATIONAL LEADERSHIP. International Journal of Psychosocial Rehabilitation. https://doi.org/10.37200/ijpr/v24i4/pr201108

Batilmurik, R. W. (2020). Individual citizenship pride: Is it the consequences of organisational citizenship behaviour-individual (OCB-I)? International Journal of Scientific and Technology Research, $9(3)$,

3429-3434. https://www.scopus.com/inward/record.uri?partnerID=HzOxMe3b\&scp=85082706859\&origin= inward

Batu, G. S. L., \& Ratnasari, S. L. (2014). Pengaruh Perilaku Individu, Kompensasi, dan Komitmen Organisasional Terhadap Kinerja Karyawan PT. Batamindo Investment Cakrawala Batam. In Jurnal Zona Manajemen.

Bol, J. (2015). Managers' discretionary adjustments: The influence of uncontrollable events and compensation interdependence. Contemporary Accounting Research, 32(1), 139-159. https://doi.org/10.1111/1911-3846.12070

Bottomley, P. (2016). The Impact of Transformational Leadership on Organizational Citizenship Behaviours: The Contingent Role of Public Service Motivation. British Journal of Management, 27(2), 390-405. https://doi.org/10.1111/1467-8551.12108

Bowling, N. (2015). Situational Strength as a Moderator of the Relationship Between Job Satisfaction and Job Performance: A Meta-Analytic Examination. Journal of Business and Psychology, 30(1), 89-104. https://doi.org/10.1007/s10869-013-9340-7

Boyatzis, R. E., \& Ron, S. (2001). Unleashing the power of self directed learning, case western reserve university. USA: Cleveland, Ohio.

Brata, Husani, Hapzi, B. H. S. A. (2017). Saudi Journal of Business and Management Studies Competitive Intelligence and Knowledge Management: An Analysis of the Literature. Saudi Journal of Business and Management Studies. https://doi.org/10.21276/sjbms

Bustomi, S., Purbangkoro, M., \& ... (2017). Pengaruh Karakteristik Individu dan Komitmen Organisasi terhadap Kinerja Karyawan melalui Kepuasan Kerja. BISMA: Jurnal Bisnis Dan .... https://jurnal.unej.ac.id/index.php/BISMA/article/view/5933

Chauhan, R., Ali, H., \& Munawar, N. A. (2019). BUILDING PERFORMANCE SERVICE THROUGH TRANSFORMATIONAL LEADERSHIP ANALYSIS, WORK STRESS AND WORK MOTIVATION (EMPIRICAL CASE STUDY IN STATIONERY DISTRIBUTOR

COMPANIES). Dinasti International Journal of Education Management And Social Science. https://doi.org/10.31933/dijemss.v1i1.42

Chhetri, P. (2014). The role of cognitive and affective trust in the relationship between organizational justice and organizational citizenship behavior: A conceptual framework. Business: Theory and Practice, 15(2), 170-178. https://doi.org/10.3846/btp.2014.17

Chidir, G. (2020). The role of organizational commitment, organizational culture and mediator organizational citizenship behavior (OCB) on employees' performance: Evidence from Indonesian automotive industry. International Journal of Control and Automation, 13(2), 615633.

https://www.scopus.com/inward/record.uri?partnerID=HzOxMe3b\&scp=85084156328\&origin= inward

Diantono, V. M. A. (2015). Pengaruh motivasi dan kepribadian terhadap kinerja karyawan melalui organizational citizenship behavior (OCB) pada karyawan STIE Mandala Jember. repository.unej.ac.id. https://repository.unej.ac.id/handle/123456789/71296

Djoko Setyo Widodo, P. Eddy Sanusi Silitonga, \& H. A. (2017). Organizational Performance : Analysis 
of Transformational Leadership Style and Organizational Learning. Saudi Journal of Humanities and Social Sciences. https://doi.org/10.21276/sjhss.2017.2.3.9

Driyantini, E., Pramukaningtiyas, H. R. P., \& ... (2020). FLEXIBLE WORKING SPACE, BUDAYA KERJA BARU UNTUK TINGKATKAN PRODUKTIVITAS DAN KINERJA ORGANISASI. ... Ilmu Dan Praktek .... http://jia.stialanbandung.ac.id/index.php/jia/article/view/584

Elmi, F., Setyadi, A., Regiana, L., \& Ali, H. (2016). Effect of leadership style, organizational culture and emotional intelligence to learning organization: On the Human Resources Development Agency of Law and Human Rights, Ministry of Law and Human Rights. International Journal of Economic Research.

Gozali, L. A., Lubis, Y., \& Syaifuddin, S. (2020). Pengaruh Motivasi Kerja dan Budaya Kerja Terhadap Produktivitas Kerja Karyawan di Kebun Huta Padang PT. Perkebunan Nusantara III (PERSERO) $\begin{array}{lllllll}\text { Kabupaten } & \ldots & \ldots & \text { J } & \text { Jurnal } & \text { Ilmiah } & \text { Magister }\end{array}$ http://jurnalmahasiswa.uma.ac.id/index.php/agrisains/article/view/298

Gumilar, G. S. (2020). PENERAPAN BUDAYA KERJA INDUSTRI DI SMKN 2 KOTA BANDUNG. repository.upi.edu. http://repository.upi.edu/id/eprint/51287

Gunnesch-Luca, G. (2020). Development and validation of a German language unit-level organizational citizenship behavior (OCB) scale. European Journal of Psychological Assessment, 36(5), 852863. https://doi.org/10.1027/1015-5759/a000558

Haeriah, H. (2012). Pengaruh Budaya Organisasi dan Perilaku Kerja Individu terhadap Kinerja Karyawan pada Koperasi Simpan Pinjam Solidaritas Polewali Mandar. repositori.uinalauddin.ac.id. http://repositori.uin-alauddin.ac.id/5401/

Halim, A. N., \& Dewi, M. B. (2018). Analisa Pengaruh Organizational Citizenship Behavior terhadap Kinerja Karyawan Hotel Bintang 3 di Surabaya. Jurnal Hospitality Dan Manajemen Jasa. http://publication.petra.ac.id/index.php/manajemen-perhotelan/article/view/7472

Hamzah, M. I., \& Sarwoko, E. (2020). Kepemimpinan, budaya organisasi dan kinerja: peran mediasi motivasi kerja. Jurnal Ekonomi Modernisasi. http://ejournal.unikama.ac.id/index.php/JEKO/article/view/4775

Handayani, Y. T. (2017). ... KARAKTERISTIK INDIVIDU, BUDAYA ORGANISASI DAN MOTIVASI KERJA TERHADAP KINERJA KARYAWAN MELALUI ORGANIZATIONAL CITIZENSHIP ... Jurnal Penelitian IPTEKS. http://jurnal.unmuhjember.ac.id/index.php/PENELITIAN_IPTEKS/article/view/1894

Handayati, R. (2016). Pengaruh Karakteristik Individu terhadap Kinerja Karyawan di Bank Jatim Cabang Lamongan (Suatu Studi pada Bank Jatim Cabang Lamongan). In Jurnal Penelitian Ekonomi dan Akuntansi ... http://jurnalekonomi.unisla.ac.id/index.php/jpensi/article/download/83/82

Harini, S., Hamidah, Luddin, M. R., \& Ali, H. (2020). Analysis supply chain management factors of lecturer's turnover phenomenon. International Journal of Supply Chain Management.

Haryanti, N. (2020). Pengaruh karakteristik individu, kecerdasan spriritual dan Organizational Citizenship Behavior (OCB) terhadap kinerja pegawai Kementerian Agama Kabupaten .... digilib.uinsgd.ac.id. http://digilib.uinsgd.ac.id/34098/

Hasanah, S. Q. (2018). PENGARUH LINGKUNGAN KERJA, KARAKTERISTIK INDIVIDU DAN DISIPLIN KERJA TERHADAP KINERJA KARYAWAN PT. MITRATANI DUA TUJUH JEMBER. repository.unmuhjember.ac.id. http://repository.unmuhjember.ac.id/8197/

Hewagama, G. (2019). Service recovery through empowerment? HRM, employee performance and job satisfaction in hotels. International Journal of Hospitality Management, 81, 73-82. https://doi.org/10.1016/j.ijhm.2019.03.006

Hidayah, R. (2019). Pengaruh Kecerdasan Spiritual terhadap Kinerja Karyawan melalui Organizational Citizenship Behavior pada PT PLN (Persero) Area Bojonegoro. Jurnal Ilmu Manajemen (JIM). https://jurnalmahasiswa.unesa.ac.id/index.php/jim/article/view/25035

Hidayanti, D. M. (2014). ... Budaya Organisasi, Kepuasan Kerja dan Kecerdasan Emosional terhadap Kinerja Pegawai melalui Organizational Citizenship Behavior (OCB) pada Yayasan Al .... repository.unej.ac.id. https://repository.unej.ac.id/handle/123456789/60204

Hidayat, A. (2017). Budaya Kerja, Kepuasan Kerja Dan Kinerja Pegawai Pt. Trijaya Medika Farma: 
Motivasi Sebagai Moderator. Sains: Jurnal Manajemen Dan Bisnis. http://jurnal.untirta.ac.id/index.php/jsm/article/view/4274

Hidayat, Y. (2018). Pengaruh Gaya Kepemimpinan, Lingkungan Kerja, Reward, Budaya Organisasi dan Karakteristik Individu Terhadap Kinerja Karyawan Pada Perum Damri Cabang .... digilib.unila.ac.id. http://digilib.unila.ac.id/30514/

Hu, J. (2016). The motivational antecedents and performance consequences of corporate volunteering: When do employees volunteer and when does volunteering help versus harm work performance? Organizational Behavior and Human Decision Processes, 137, 99-111. https://doi.org/10.1016/j.obhdp.2016.08.005

Hui, C. (2015). Organizational Inducements and Employee Citizenship Behavior: The Mediating Role of Perceived Insider Status and the Moderating Role of Collectivism. Human Resource Management, 54(3), 439-456. https://doi.org/10.1002/hrm.21620

Islamiyah, I. (2019). PENGARUH LINGKUNGAN KERJA, KARAKTERISTIK INDIVIDU, DAN KARAKTERISTIK PEKERJAAN TERHADAP KINERJA KARYAWAN DENGAN MOTIVASI .... eprintslib.ummgl.ac.id. http://eprintslib.ummgl.ac.id/id/eprint/927

Ismariana, P., Hidayat, W., \& ... (2015). Pengaruh Budaya Kerja, Disiplin Kerja Dan K3 Terhadap Kinerja Karyawan Tetap Bagian Produksi Unit Spinning 2 Pada PT Apac Inti Corpora. Jurnal Ilmu Administrasi .... https://ejournal3.undip.ac.id/index.php/jiab/article/view/8228

Isnaini, F. Z., Suharyono, B. S., \& ... (2018). Pengaruh kepuasan kerja terhadap kinerja karyawan dengan variabel mediator Organizational Citizenship Behavior (OCB)(Studi pada karyawan Hotel Sahid

Jurnal

http://administrasibisnis.studentjournal.ub.ac.id/index.php/jab/article/view/2603

ISNAINI, M. (2019). PENGARUH MOTIVASI, LINGKUNGAN KERJA DAN BUDAYA KERJA TERHADAP KINERJA KARYAWAN PADA PT ARMADA PAGORA JAYA KEDIRI. repository.unik-kediri.ac.id. http://repository.unik-kediri.ac.id/id/eprint/39

Janati, N. (2019). PENGARUH LINGKUNGAN KERJA DAN KARAKTERISTIK INDIVIDU TERHADAP KINERJA KARYAWAN PADA PT. PLN (PERSERO) UP3 MEDAN.

repository.umsu.ac.id. http://repository.umsu.ac.id/handle/123456789/6525

Januar, A. C. (2020). pengaruh organizational citizenship behavior (OCB), kepemipinan, karakteristik individu terhadap kinerja guru dengan kompetensi sebagai variabel intervening pada .... repository.unmuhjember.ac.id. http://repository.unmuhjember.ac.id/id/eprint/8449

Jayanti, G. A., \& Nazwirman, N. (2020). Model Kinerja Pegawai: Kepemimpinan, Budaya Kerja, dan Motivasi Kerja dengan Kepuasan kerja variabel intervening. Jurnal Ilmiah Manajemen Dan Bisnis. http://journal.umsu.ac.id/index.php/mbisnis/article/view/4582

Junawar, S., Patwayati, P., Sukotjo, E., \& Rommy, N. (n.d.). PENGARUH KOMITMEN ORGANISASI TERHADAP ORGANIZATIONAL CITIZENSHIP BEHAVIOR DAN KINERJA PEGAWAI. Jurnal Manajemen, Bisnis Dan http://ojs.uho.ac.id/index.php/JUMBO/article/view/8001

Jung, H. (2015). The impact of employees' positive psychological capital on job satisfaction and organizational citizenship behaviors in the hotel. International Journal of Contemporary Hospitality Management, 27(6), 1135-1156. https://doi.org/10.1108/IJCHM-01-2014-0019

Kampkötter, P. (2017). Performance appraisals and job satisfaction. International Journal of Human Resource Management, 28(5), 750-774. https://doi.org/10.1080/09585192.2015.1109538

Karim, A. (2010). Pengaruh disiplin, etos kerja, dan budaya organisasi terhadap organizational citizenship behavior pegawai administrator Pelabuhan Tanjung Priok. Widyariset. https://widyariset.pusbindiklat.lipi.go.id/index.php/widyariset/article/view/129

KARYONO, F. (2020). PENGARUH BUDAYA ORGANISASI, LINGKUNGAN KERJA, DAN KARAKTERISTIK INDIVIDU TERHADAP KINERJA KARYAWAN PT. STARS

INTERNASIONAL. repository.mahardhika-library.id. http://repository.mahardhikalibrary.id/1432/

Keller, J. R. (2018). Posting and Slotting: How Hiring Processes Shape the Quality of Hire and Compensation in Internal Labor Markets. Administrative Science Quarterly, 63(4), 848-878. https://doi.org/10.1177/0001839217736045 
Kimbal, F. F. M., Sendow, G. M., \& ... (2015). Beban kerja, organizational citizenship behavior, dan keterlibatan kerja pengaruhnya terhadap kinerja karyawan PT. PLN (Persero) wilayah Suluttenggo Area $\quad . . \quad$ Jurnal EMBA: Jurnal Riset https://ejournal.unsrat.ac.id/index.php/emba/article/view/9285

Kolompoy, C., Ilat, V., \& Sabijono, H. (2015). Pengaruh Perilaku Individu Wajib Pajak Orang Pribadi Terhadap Penggunaan E-filing di Kota Manado. ACCOUNTABILITY. https://ejournal.unsrat.ac.id/index.php/accountability/article/view/10524

Koning, L. (2015). How leaders' emotional displays shape followers' organizational citizenship behavior. Leadership Quarterly, 26(4), 489-501. https://doi.org/10.1016/j.leaqua.2015.03.001

Kridharta, D., \& Rusdianti, E. (2017). Analisis pengaruh karakteristik individu, komitmen organisasi, dan kepuasan kerja terhadap kinerja karyawan dengan motivasi sebagai variabel intervening. Jurnal Riset Ekonomi Dan Bisnis. http://journals.usm.ac.id/index.php/jreb/article/view/882

KURNIASARI, R. (2020). PENGARUH LINGKUNGAN KERJA DAN PERILAKU INDIVIDU TERHADAP KINERJA KARYAWAN MELALUI MOTIVASI KERJA PADA DEVISI

MAINTENANCE $\quad P T \quad \ldots \quad$ repository.mahardhika-library.id. http://repository.mahardhikalibrary.id/1449/

Kurniawan, F. (2019). PENGARUH BUDAYA KERJA DAN MOTIVASI KERJA TERHADAP KINERJA KARYAWAN DENGAN KEPUASAN KERJA SEBAGAI VARIABEL INTERVENING. digilib.unila.ac.id. http://digilib.unila.ac.id/id/eprint/58609

Kurniawan, R. A., Qomariah, N., \& ... (2019). Dampak Organizationlal Citizenship Behavior, Motivasi Kerja, Dan Kepuasan Kerja Terhadap Kinerja Karyawan. Jurnal Penelitian .... http://jurnal.unmuhjember.ac.id/index.php/PENELITIAN_IPTEKS/article/view/2453

Kusumawardani, M. R., \& ... (2018). Budaya Organisasi dan Kepuasan Kerja Terhadap Organizational Citizenship Behavior Melalui Komitmen Organisasi Sebagai Variabel Moderating. Akutansi Bisnis \& .... http://journal.stie-mce.ac.id/index.php/jabm/article/view/379

Lamalewa, F. (2018). The influence of practices of human resources management, compensation, work satisfaction and motivation on performance of bank employees in Merauke City. International Journal of Mechanical Engineering and Technology, 9(10), 64-71. https://www.scopus.com/inward/record.uri?partnerID=HzOxMe3b\&scp=85056003758\&origin= inward

Lambey, B., Lengkong, V. P. K., \& ... (2020). PENGARUH PENEMPATAN PEGAWAI SERTA BUDAYA KERJA TERHADAP KINERJA PEGAWAI DENGAN KEPUASAN KERJA SEBAGAI VARIABLE INTERVENING .... JMBI UNSRAT (Jurnal ....

https://ejournal.unsrat.ac.id/index.php/jmbi/article/view/30341

Lavy, S. (2017). My Better Self: Using Strengths at Work and Work Productivity, Organizational Citizenship Behavior, and Satisfaction. Journal of Career Development, 44(2), 95-109. https://doi.org/10.1177/0894845316634056

Lee, M. T. (2016). Understanding employee motivation and organizational performance: Arguments for a set-theoretic approach. Journal of Innovation and Knowledge, 1(3), 162-169. https://doi.org/10.1016/j.jik.2016.01.004

Lestari, E. R., \& Ghaby, N. K. F. (2018). Pengaruh Organizational Citizenship Behavior (OCB) terhadap kepuasan kerja dan kinerja karyawan. Industria: Jurnal Teknologi Dan .... https://industria.ub.ac.id/index.php/industri/article/view/350

Li, M. (2016). Linking empowering leadership and change-oriented organizational citizenship behavior: The role of thriving at work and autonomy orientation. Journal of Organizational Change Management, 29(5), 732-750. https://doi.org/10.1108/JOCM-02-2015-0032

Limakrisna, N., Noor, Z. Z., \& Ali, H. (2016). Model of employee performance: The empirical study at civil servants in government of west java province. International Journal of Economic Research.

Lishandy, N. P. (2018). Pengaruh Karakteristik Individu Terhadap Kinerja Karyawan Dengan Motivasi Kerja Sebagai Variabel Intervening (Studi pada Karyawan PT. Three "A” Technic Candi .... repository.ub.ac.id. http://repository.ub.ac.id/166084/

Lofquist, E. (2018). Viking leadership: How Norwegian transformational leadership style effects creativity and change through organizational citizenship behavior (OCB). International Journal 
of Cross Cultural Management, 18(3), 309-325. https://doi.org/10.1177/1470595818806326

Lovihan, M. A. K. (2014). Pengaruh Persepsi Budaya Organisasi terhadap Kinerja Karyawan Dimediasi oleh Organizational Citizenship Behavior. Jurnal Psikologi Tabularasa. http://jurnal.unmer.ac.id/index.php/jpt/article/view/223

Lubis, Y. (2013). Pengaruh Karakteristik Individu, Karakteristik Pekerjaan, Iklim Organisasi terhadap Kepuasan dan Kinerja Karyawan. In Jurnal Trikonomika.

Luna-Arocas, R. (2015). Talent management, talent mindset competency and job performance: The mediating role of job satisfaction. European Journal of International Management, 9(1), 28-51. https://doi.org/10.1504/EJIM.2015.066670

Lutfiyah, L., Oetomo, H. W., \& Suhermin, S. (2020). Pengaruh Kompetensi dan Budaya Kerja terhadap Person Job Fit dan Kinerja Karyawan pada PT. Andromedia. Jurnal Ilmu Manajemen. https://journal.unesa.ac.id/index.php/jim/article/view/7767

Luthan, F. (2009). International management: Culture, strategy, and behavior. In Journal of Experimental Psychology: General.

MacKenzie, S. B., Podsakoff, P. M., \& Ahearne, M. (1998). Some possible antecedents and consequences of in-role and extra-role salesperson performance. Journal of Marketing, 62(3), 8798.

Maesaroh, S., Asbari, M., Hutagalung, D., \& ... (2020). PengaruhReligiusitas dan Kepemimpinan Transformasional terhadap KinerjaGuru melalui Mediasi Organizational Citizenship Behavior. EduPsyCouns .... https://ummaspul.e-journal.id/Edupsycouns/article/view/473

Mahayasa, I. A., Sintaasih, D. K., \& Putra, M. S. (2018). Pengaruh Kepuasan Kerja Dan Budaya Organisasi Terhadap Komitmen Organisasional dan Organizational Citizenship Behavior Perawat. In Matrik: Jurnal Manajemen https://ojs.unud.ac.id/index.php/jmbk/article/download/36160/22933

Mahmudi, K., \& Surjanti, J. (2020). Analisis Pengaruh Kepuasan Kerja, Budaya Organisasi dan Kompetensi terhadap Organizational Citizenship Behavior pada PT. Mubarak Ainama Kunt Surabaya. Jurnal Ilmu Manajemen. https://journal.unesa.ac.id/index.php/jim/article/view/8840

Mangkunegara, A. A. (n.d.). Anwar Prabu. 2011. Manajemen Sumber Daya Manusia Perusahaan.

Marinda, V. (2019). Influence of transformational leadership and employee engagement to organizational citizenship behavior (OCB) and also the effect to division effectiveness at PT. X. Journal of Advanced Research in Dynamical and Control Systems, 11(3), 549-556. https://www.scopus.com/inward/record.uri?partnerID=HzOxMe3b\&scp=85069874024\&origin= inward

Mariniharsi, S. K., Hidayati, T., \& ... (2020). Pengaruh karakteristik individu dan karakteristik pekerjaan terhadap kepuasan kerja serta kinerja pegawai negeri sipil. Jurnal Ilmu .... http://journal.feb.unmul.ac.id/index.php/JIMM/article/view/2857

Marlina, E., Wulandari, N., \& ... (2020). Peran Organizational Citizenship Behavior pada Pengaruh Budaya Organisasi dan Komitmen Organisasi Terhadap Kinerja Karyawan SKK Migas. ... Riau Accounting and .... http://ejurnal.umri.ac.id/index.php/MRABJ/article/view/2131

Masydzulhak, P. D., Ali, P. D. H., \& Anggraeni, L. D. (2016). The Influence of work Motivationand Job Satisfaction on Employee Performance and Organizational Commitment Satisfaction as an Intervening Variable in PT. Asian Isuzu Casting Center. In Journal of Research in Business and Management.

Mattalatta, S. (2019). Pengaruh Kepemimpinan Situasional Terhadap Kepuasan Kerja, Organizational Citizenship Behavior Dan Kinerja Karyawan Pada Perusahaan Keluarga (Studi .... MANDAR: Management Development and Aplied https://ojs.unsulbar.ac.id/index.php/mandar/article/view/320

Maysarah, S., \& Rahardjo, M. (2015). Analisis Pengaruh Budaya Organisasi, Keadilan Organisasi, dan Komitmen Organisasional Terhadap Organizational Citizenship Behavior (Studi Pada PT Kereta $\begin{array}{lccc}\text { Api } & \ldots . & \text { Diponegoro } & \text { Journal }\end{array}$ https://ejournal3.undip.ac.id/index.php/djom/article/view/13287

McDonnell, A. (2016). Beyond managerial talent: 'key group' identification and differential compensation practices in multinational companies. International Journal of Human Resource 
Management, 27(12), 1299-1318. https://doi.org/10.1080/09585192.2015.1075571

Meneghel, I. (2016). From social context and resilience to performance through job satisfaction: A multilevel study over time. Human Relations, 69(11), 2047-2067. https://doi.org/10.1177/0018726716631808

Menguc, B. (2016). When does (Mis)Fit in customer orientation matter for frontline employees' job satisfaction and performance? Journal of Marketing, 80(1), 65-83. https://doi.org/10.1509/jm.15.0327

Miftah, T. (2015). Perilaku Organisasi Konsep dasar dan aplikasinya.

Mo, S. (2017). Linking Ethical Leadership to Employees' Organizational Citizenship Behavior: Testing the Multilevel Mediation Role of Organizational Concern. Journal of Business Ethics, 141(1), 151-162. https://doi.org/10.1007/s10551-015-2734-x

Ocampo, L. (2018). A historical review of the development of organizational citizenship behavior (OCB) and its implications for the twenty-first century. In Personnel Review (Vol. 47, Issue 4, pp. 821-862). https://doi.org/10.1108/PR-04-2017-0136

Ocampo, L. A. (2018). Using fuzzy DEMATEL in modeling the causal relationships of the antecedents of organizational citizenship behavior (OCB) in the hospitality industry: A case study in the Philippines. Journal of Hospitality and Tourism Management, 34, 11-29. https://doi.org/10.1016/j.jhtm.2017.11.002

Oktiani, N., Kurniasari, R., \& Utami, C. P. (2019). Pelatihan dan Budaya Kerja Dalam Upaya Peningkatan Produktivitas Kerja. Jurnal Kajian Ilmiah. http://www.jurnal.ubharajaya.ac.id/index.php/kajian-ilmiah/article/view/423

Organ, D. W. (1988). Organizational citizenship behavior: The good soldier syndrome. Lexington Books/DC Heath and Com.

Osman, A. (2015). The influence of job satisfaction, job motivation \&amp; perceived organizational support towards organizational citizenship behavior (OCB): A perspective of American-Based Organization in Kulim, Malaysia. Asian Social Science, 11(21), 174-182. https://doi.org/10.5539/ass.v11n21p174

Pahlawan, F., \& Prabowo, C. B. A. (2020). Pengaruh Karakteristik Individu, Intensitas Penggunaan Smartphone Dan Interaksi Sosial Terhadap Perilaku Phone And Snubbing Karyawan Lifepal®. In Syntax. jurnal.syntax-idea.co.id. http://jurnal.syntax-idea.co.id/index.php/syntaxidea/article/download/257/288

Paille, P. (2009). Commitment and citizenship in organizational context: An empirical study on the contribution of multi foci of commitment to predict organizational citizenship behaviour. Travail Humain, 72(2), 185-204. https://doi.org/10.3917/th.722.0185

Pan, F. (2015). Practical application of importance-performance analysis in determining critical job satisfaction factors of a tourist hotel. Tourism Management, 46, 84-91. https://doi.org/10.1016/j.tourman.2014.06.004

Pancaria, R. (2014). Pengaruh Perilaku Individu Dan Budaya Organisasi Terhadap Kinerja Karyawan Pada PT. Bank Sulselbar Cabang Makassar. repositori.uin-alauddin.ac.id. http://repositori.uinalauddin.ac.id/11193/

Papa, A. (2018). Improving innovation performance through knowledge acquisition: the moderating role of employee retention and human resource management practices. Journal of Knowledge Management, 24(3), 589-605. https://doi.org/10.1108/JKM-09-2017-0391

Paulus, A. Y. (2019). Pengaruh Faktor Ibu dan Budaya Kerja Berat Saat Hamil Terhadap Kejadian BBLR di Kota Kupang. CHMK MIDWIFERY SCIENTIFIC. http://www.cyberchmk.net/ojs/index.php/bidan/article/view/472

Pedaran, N. (2012). A study of emotional intelligence domination levels and effects on the emergence of organizational citizenship behavior. International Journal of Knowledge, Culture and Change Management, 11(5), 135-145. https://doi.org/10.18848/1447-9524/cgp/v11i05/50194

Peoni, H. (2014). Pengaruh karakteristik individu dan lingkungan kerja terhadap kinerja karyawan (Studi Pada PT. Taspen (Persero) Cabang Manado). JURNAL ADMINISTRASI BISNIS (JAB), 3(001).

Permatasari, W. F. E. (2020). Hubungan antara lingkungan, perilaku individu dan pengetahuan tentang 
skabies dengan kejadian skabies di Panti Asuhan NU Nurur Rohmah Bojonegoro. erepository.uwks.ac.id. https://erepository.uwks.ac.id/6141/

Prasetyo, A. D., \& Nugraheni, V. (2020). Pengaruh budaya kerja, pelatihan, pendidikan, kompensasi, dan lingkungan kerja terhadap prestasi kerja karyawan iconmall gresik jawa timur. Journal Fakultas Ekonomi .... https://ejournal.unitomo.ac.id/index.php/fe/article/view/3010

PRASETYO, D. N. (2019). PENGARUH MOTIVASI KERJA, LINGKUNGAN KERJA, KEPEMIMPINAN, DAN BUDAYA KERJA TERHADAP KINERJA PEGAWAI PADA DINAS PERHUBUNGAN .... eprints.umg.ac.id. http://eprints.umg.ac.id/3235/

Putra, D., Idris, M., \& Maryadi, M. (2020). PENGARUH KOMPETENSI, MOTIVASI KERJA DAN BUDAYA ORGANISASI TERHADAP KINERJA PEGAWAI PADA DINAS PERHUBUNGAN KABUPATEN ... Jurnal Magister .... https://e-jurnal.stienobelindonesia.ac.id/index.php/JMMNI/article/view/997

Putra, R B. (2016). Efek Mediasi Kepuasan Kerja terhadap Kinerja dengan Komitmen Organisasi, Komunikasi Interpersonal dan Organizational Citizenship Behaviors sebagai Variabel .... Jurnal Praktik Bisnis. http://ejournal.unp.ac.id/index.php/d3fe/article/view/6353

Putra, R B, Elfiswandi, E., Fitri, H., \& ... (2020). The Effect of Business Knowledge and SelfConfidence on Business Performance With Business Innovation as Mediating Variable Among SMEs in Padang City. ... of Entrepreneurship and .... https://www.atlantispress.com/proceedings/icebm-19/125941552

Putra, Ramdani Bayu. (2018). Effect Of Organization Commitment Mediation To Organizational Citizenship Behaviors With Interpersonal Communication And Work Satisfaction As Antesedent Variable. Jurnal Apresiasi Ekonomi, 6(1), 8-22. https://doi.org/10.31846/jae.v6i1.29

Ramdhani, D. A. (2020). Analisis Pengaruh Karakteristik Pekerjaan Dan Karakteristik Individu Terhadap Kinerja Karyawan Dengan Motivasi Kerja Sebagai Variabel Mediasi Pada Unit Bisnis .... repository.unair.ac.id. http://repository.unair.ac.id/id/eprint/94778

Ramdhani, D. A., \& Sridadi, A. R. (2019). PENGARUH KARAKTERISTIK PEKERJAAN DAN KARAKTERISTIK INDIVIDU TERHADAP KINERJA KARYAWAN MELALUI MOTIVASI KERJA SEBAGAI VARIABEL $\quad . . . \quad$ Competence $\quad . . . \quad$ https://ecoentrepreneur.trunojoyo.ac.id/kompetensi/article/view/6827

Rasmikayati, E., Kusumo, R. A. B., Sukayat, Y., \& ... (2020). Karakteristik Individu Dan Usahatani Petani Mangga Yang Melakukan Kemitraan Pemasaran Di Kecamatan Sindangkasih Kabupaten Majalengka. Paradigma .... http://jurnal.unswagati.ac.id/index.php/JPA/article/view/3544

RATIH, D. J. (2020). KONSEP DIRI INDIVIDU PERILAKU HOMOSEKSUAL (Studi Fenomenologi Seorang Homoseksual dalam Interaksi Sosial di Wilayah Bogor). repository.mercubuana.ac.id. https://repository.mercubuana.ac.id/56526/

Ratnasari, S. L., Buulolo, M., \& ... (2020). Analisis Karakteristik Individu, Lingkungan Kerja, Iklim Organisasi, Motivasi, Dan Kompensasi Terhadap Kinerja Karyawan. In ... : JURNAL Manajemen dan .... journal.unifa.ac.id. https://journal.unifa.ac.id/index.php/manor/article/view/175/145

Ravichandran, S. (2007). Formation of organizational citizenship behaviors in students employed in university dining services: Impact of manager and co-worker behaviors. Journal of Foodservice Business Research, 10(2), 19-50. https://doi.org/10.1300/J369v10n02_03

Rejeki, D. (2019). An empirical investigation of organizational citizenship behavior (OCB): The way to improve performance in higher education institutions. International Journal of Scientific and $\begin{array}{lll}\text { Technology Research, } & \text { 8(9), 1680-1682. }\end{array}$ https://www.scopus.com/inward/record.uri?partnerID=HzOxMe3b\&scp=85073451125\&origin= inward

Ridwan, M., Mulyani, S. R., \& Ali, H. (2020). Building behavior and performance citizenship: Perceived organizational support and competence (case study at SPMI private university in west Sumatra). International Journal of Psychosocial Rehabilitation. https://doi.org/10.37200/IJPR/V24I6/PR260195

Riyanto, S., Pratomo, A., \& Ali, H. (2017). EFFECT OF COMPENSATION AND JOB INSECURITY ON EMPLOYEE ENGAGEMENT (STUDY ON EMPLOYEE OF BUSINESS COMPETITION SUPERVISORY COMMISSION SECRETARIAT). International Journal of Advanced Research.https://doi.org/10.21474/iiar01/4139 
Riyanto, S., Sutrisno, A., \& Ali, H. (2017). International Review of Management and Marketing The Impact of Working Motivation and Working Environment on Employees Performance in Indonesia Stock Exchange. International Review of Management and Marketing.

Rizqina, Z. A., Adam, M., \& Chan, S. (2017). Pengaruh budaya kerja, kemampuan, dan komitmen kerja terhadap kepuasan kerja pegawai serta dampaknya terhadap kinerja Badan Pengusahaan Kawasan .... Jurnal Magister .... http://e-repository.unsyiah.ac.id/JMM/article/view/9267

RO'UF, E. J. (2018). ANALISIS PENGARUH HUMAN RELATION DAN PERILAKU INDIVIDU TERHADAP KINERJA KARYAWAN DI TOKO ER COLLECTION PONOROGO. eprints.umpo.ac.id. http://eprints.umpo.ac.id/3801/

Robbins, S. P. (n.d.). Dan Timothy A. Judge. 2015. Organizational Behavior, 15.

Robbins, S. P. J. (2008). Perilaku Organisasi, Edisi Bahasa Indonesia. In Perilaku Organisasi. Edisi Bahasa Indonesia PT Mancanan Jaya Cemerlang. Jakarta.

Rodríguez, D. (2016). Impact of Lean Production on Perceived Job Autonomy and Job Satisfaction: An Experimental Study. Human Factors and Ergonomics In Manufacturing, 26(2), 159-176. https://doi.org/10.1002/hfm.20620

ROMADHONA, M. K. (2019). ... KESESUAIAN NILAI-NILAI INDIVIDU DENGAN PERUSAHAAN TERHADAP KINERJA KARYAWAN DENGAN KOMITMEN ORGANISASIONAL DAN PERILAKU .... eprints.upnyk.ac.id. http://eprints.upnyk.ac.id/19491/

Romel, D. (2013). Pengaruh Karakteristik Individu terhadap Kepuasan Kerja dan Implikasinya pada Kinerja Karyawan di Unikom. In Jurnal Manajemen. academia.edu. https://www.academia.edu/download/43506312/jbptunikompp-gdl-dianromeln-30920-11unikom_d-1.pdf

Sakti, O., \& Sukartini, N. M. (2020). Karakteristik Individu dan Perilaku Peduli Lingkungan: Penggunaan Listrik. IJEEM-Indonesian Journal of Environmental http://journal.unj.ac.id/unj/index.php/ijeem/article/view/12158

Saragih, N M. (2020). PENGARUH KEPEMIMPINAN DAN KARAKTERISTIK INDIVIDU TERHADAP ORGANIZATIONAL CITIZENSHIP BEHAVIOR PADA PT. UNITED TRACTORS TBK .... Accumulated Journal (Accounting and .... http://e-journal.potensiutama.ac.id/ojs/index.php/Accumulated/article/view/979

Saragih, Nahar Maganda. (2020). PENGARUH KEPEMIMPINAN DAN KARAKTERISTIK INDIVIDU TERHADAP ORGANIZATIONAL CITIZENSHIP BEHAVIOR PADA PT. UNITED TRACTORS TBK CABANG MEDAN. Accumulated Journal (Accounting and Management Research Edition), 2(2), 111-123.

Sari, A. R., Rahman, F., Wulandari, A., Pujianti, N., Laily, N., \& ... (2020). Perilaku Pencegahan Covid19 Ditinjau dari Karakteristik Individu dan Sikap Masyarakat. JPPKMI. https://journal.unnes.ac.id/sju/index.php/jppkmi/article/view/41428

Sari, S. A. (2016). ... BUDAYA ORGANISASI TERHADAP KINERJA KARYAWAN MELALUI ORGANIZATIONAL CITIZENSHIP BEHAVIOUR SEBAGAI VARIABEL INTERVENING. $\begin{array}{lc}\text { Jurnal } & \text { Ilmu } \\ \text { https://jurnalmahasiswa.unesa.ac.id/index.php/jim/article/view/16893 }\end{array}$

SARI, S. D. (2015). Pengaruh Karakteristik Individu Dan Lingkungan Kerja Terhadap Kinerja Karyawan Pada Sentra Industri Kerajinan Kulit Di Manding Kabupaten Bantul Yogyakarta. Universitas PGRI Universitas. http://repository.upy.ac.id/id/eprint/239

Sariningtyas, E. R. W., \& Sulistiyani, S. (2016). Analisis Karakteristik Individu Dan Motivasi Intrinsik Terhadap Komitmen Organisasi Dengan Kepuasan Kerja Sebagai Variabel Intervening (Studi pada PDAM Tirta .... Serat Acitya. http://jurnal.untagsmg.ac.id/index.php/sa/article/view/325

Schein, E. H. (2010). Organizational culture and leadership (Vol. 2). John Wiley \& Sons.

Schwatka, N. V. (2017). Health risk factors as predictors of workers' compensation claim occurrence and cost. Occupational and Environmental Medicine, 74(1), 14-23. https://doi.org/10.1136/oemed-2015-103334

Sedarmayanti, S., \& Rahadian, N. (2018). Hubungan Budaya Kerja dan Lingkungan Kerja Terhadap Peningkatan Kinerja Pegawai Pada Lembaga Pendidikan Tinggi. Jurnal Ilmu Administrasi .... http://jia.stialanbandung.ac.id/index.php/jia/article/view/133

Setiawan, A., \& Bodroastuti, T. (2010). Pengaruh Karakteristik Individu dan Faktor-Faktor Pekerjaan Terhadap Motivasi (Studi Pada Karyawan CV. Bintang Timur Semarang). Jurnal Kajian Akuntansi Dan Bisnis, 1(1), 102937. 
Setyaningsih, U. (2019). PENGARUH LINGKUNGAN KERJA, KARAKTERISTIK INDIVIDU DAN DISIPLIN KERJA TERHADAP KINERJA KARYAWAN DI PT. DELTA MINA PERKASA .... repo.iain-tulungagung.ac.id. http://repo.iain-tulungagung.ac.id/id/eprint/10567

Sharma, P. (2016). Internal service quality as a driver of employee satisfaction, commitment and performance: Exploring the focal role of employee well-being. Journal of Service Management, 27(5), 773-797. https://doi.org/10.1108/JOSM-10-2015-0294

Shodiyah, I. A. (2017). Pengaruh Disiplin Kerja, Motivasi Berprestasi, dan Budaya Kerja terhadap Prestasi Kerja pada Guru SMKN 1 Jember. repository.unmuhjember.ac.id. http://repository.unmuhjember.ac.id/id/eprint/1359

Sidin, A. I. (2020). Can Buginese values foster the organizational citizenship behavior (OCB) of civil servants in local hospital in Makassar, South Sulawesi, Indonesia. Enfermeria Clinica, 30, 229232. https://doi.org/10.1016/j.enfcli.2020.06.052

Silitonga, P. E. S., Widodo, D. S., \& Ali, H. (2017). Analysis of the effect of organizational commitment on organizational performance in mediation of job satisfaction (Study on Bekasi City Government). International Journal of Economic Research.

Simanjuntak, D. A., Siregar, R. T., Sisca, S., \& ... (2020). Pengaruh Ocb (Organizational Citizenship Behavior) dan Karakteristik Individu terhadap Kinerja Pegawai pada Kantor Pelayanan Kekayaan Negara dan Lelang Kota .... Maker: Jurnal ... https://www.maker.ac.id/index.php/maker/article/view/133

Sinha, S., Singh, A. K., Gupta, N., \& Dutt, R. (2010). Impact of work culture on motivation and performance level of employees in private sector companies. Acta Oeconomica Pragensia, 18(6), $49-67$.

Soepono, D. N., \& Srimulyani, V. A. (2015). Analisis pengaruh the big five personality terhadap Organizational Citizenship Behavior (OCB) dan kinerja perawat di RS Santa Clara Madiun. Jurnal Manajemen .... https://journals.telkomuniversity.ac.id/ijm/article/view/393

Sofyandi, H., \& Garniwa, I. (2007). Perilaku organisasional. Yogyakarta: Graha Ilmu.

Solechah, Q. (2013). Pengaruh Gaya Kepemimpinan Transformasional dan Karakteristik Individu Terhadap Motivasi dan Kinerja Karyawan (Studi Pada Perusahaan Umum Jasa Tirta I .... repository.ub.ac.id. http://repository.ub.ac.id/159731/

Sony, M. (2016). The relationship between emotional intelligence, frontline employee adaptability, job satisfaction and job performance. Journal of Retailing and Consumer Services, 30, 20-32. https://doi.org/10.1016/j.jretconser.2015.12.003

Suban, G. S., Tewal, B., \& ... (2020). PENGARUH KARAKTERISTIK INDIVIDU, KOMPETENSI DAN FASILITAS KERJA TERHADAP KINERJA KARYAWAN PADA PT. TROPICA

COCOPRIMA LELEMA. Jurnal EMBA: Jurnal Riset ...
https://ejournal.unsrat.ac.id/index.php/emba/article/view/30782

Subardjo. (2020). The role of job satisfaction towards organizational citizenship behavior (Ocb). International Journal of Scientific and Technology Research, 9(2), 5998-6000. https://www.scopus.com/inward/record.uri?partnerID=HzOxMe3b\&scp=85081561932\&origin= inward

Sukarman. (2018). Role of work motivation and organizational culture in improving the performance of civil servants and organizational citizenship behavior (OCB) in Boalemo District Gorontalo Province. International Journal of Scientific and Technology Research, 7(11), 44-51. https://www.scopus.com/inward/record.uri?partnerID=HzOxMe3b\&scp=85059846746\&origin= inward

Sukmawati, E., Ratnasari, S. L., \& Zulkifli, Z. (2020). PENGARUH GAYA KEPEMIMPINAN, KOMUNIKASI, PELATIHAN, ETOS KERJA, DAN KARAKTERISTIK INDIVIDU TERHADAP KINERJA KARYAWAN. In JURNAL DIMENSI. journal.unrika.ac.id. https://www.journal.unrika.ac.id/index.php/jurnaldms/article/download/2722/1893

Sulaeman, A. S., Waluyo, B., \& Ali, H. (2019). Making dual procurement and supply chain operations: Cases in the indonesian higher education. International Journal of Supply Chain Management.

SUPARDI, D. S. D., Indrawan, P., \& Arifin, C. (2020). ANALISIS BUDAYA KERJA, KOMITMEN, DAN KONFLIK KELOMPOK TERHADAP ORGANIZATIONAL CITIZENSHIP BEHAVIOR $\begin{array}{llll}\text { SERTA IMPLIKASINYA PADA } & \text {... } & \text { repository.unpas.ac.id. }\end{array}$ http://repository.unpas.ac.id/id/eprint/47947

Suparjo, D. (2016). Pengaruh komitmen organisasi, kepuasan kerja dan budaya organisasi terhadap 
organizational citizenship behavior (OCB)(Studi Pada PT. Plasa Simpanglima .... Jurnal Ilmiah Dinamika Ekonomi Dan Bisnis. http://jurnal.untagsmg.ac.id/index.php/jideb/article/view/255

SUPARMAN, L. (2014). ... INDIVIDU DAN PERSEPSI KINERJA PELAYANAN KARYAWAN BANK SYARIAH PADA SIKAP SERTA DAMPAKNYA TERHADAP PERILAKU NASABAH DI KOTA .... repository.unair.ac.id. http://repository.unair.ac.id/32447/

Supriyanto, E. (2017). Pengaruh Kepuasan Kerja dan Budaya Organisasi terhadap Kinerja Karyawan dengan Organizational Citizenship Behavior sebagai Variabel Intervening.(Studi pada ....

repository.umpwr.ac.id. http://repository.umpwr.ac.id:8080/handle/123456789/1472

Susanti, S. (2016). PENGARUH KARAKTERISTIK INDIVIDU, BUDAYA ORGANISASI, DAN KOMITMEN ORGANISASI TERHADAP KINERJA KARYAWAN DENGAN MOTIVASI SEBAGAI .... Journal of Innovation in Business and Economics. http://ejournal.umm.ac.id/index.php/jibe/article/view/3416

Susita, D. (2020). The effect of organisational climate and career development on organisational citizenship behaviour (OCB) through organisational commitment as the intervening variable. International Journal of Innovation, Creativity and Change, 12(5), 538-553. https://www.scopus.com/inward/record.uri?partnerID=HzOxMe3b\&scp=85084382480\&origin= inward

SUTRISNA, I. P. P. (2019). PENGARUH PERILAKU INDIVIDU, LINGKUNGAN PENGENDALIAN, DAN KOMPENSASI TERHADAP KECENDERUNGAN KECURANGAN AKUNTANSI (SURVEY .... repository.untad.ac.id. http://repository.untad.ac.id/1666/

Suzana, A. (2017). Pengaruh organizational citizenship behavior (ocb) terhadap kinerja karyawan (studi di: Pt. Taspen (persero) kantor cabang cirebon). LOGIKA Jurnal Ilmiah Lemlit Unswagati Cirebon. http://jurnal.unswagati.ac.id/index.php/logika/article/view/575

Syahputra, M. D. (2019). Perilaku Individu Dan Sosial Kuntul Kerbau (Bubulcus ibis) pada Area Penangkaran Buaya Asam Kumbang Kecamatan Medan Selayang Kota Medan Sumatera .... repositori.usu.ac.id. http://repositori.usu.ac.id/handle/123456789/16205

Syaifudin, Y. (2017). Pengaruh Kepemimpinan Visioner Dan Budaya Organisasi Terhadap Kinerja Pegawai Melalui Organizational Citizenship Behavior Sebagai Variabel Intervening Di .... eprints.umk.ac.id. https://eprints.umk.ac.id/7670/

Syamsuddin, N. (2020). Pengaruh Budaya Organisasi dan Karakteristik Individu terhadap Kinerja Karyawan pada Plasa Telkom Masamba. repository.umpalopo.ac.id. http://repository.umpalopo.ac.id/id/eprint/276

Syarif, F., Firman, A., \& Saripuddin, D. (2020). PENGARUH KECERDASAN INTELEKTUAL, MOTIVASI, DAN BUDAYA KERJA TERHADAP KINERJA PEGAWAI BADAN

KEUANGAN DAN ASET DAERAH $\ldots .$. Nobel $\ldots .$. https://e-jurnal.stienobelindonesia.ac.id/index.php/NMaR/article/view/968

Takeuchi, R. (2015). Too many motives? The interactive effects of multiple motives on organizational citizenship behavior. Journal of Applied Psychology, 100(4), 1239-1248. https://doi.org/10.1037/ap10000001

Tambingon, C. K., Tewal, B., \& Trang, I. (2019). Pengaruh Lingkungan Kerja, Karakteristik Individu Dan Kompetensi Terhadap Kinerja Karyawan PT. Coco Prima Lelema Indonesia. Jurnal EMBA: Jurnal Riset .... https://ejournal.unsrat.ac.id/index.php/emba/article/view/25280

Tanasal, R., \& Kojo, C. (2016). ANALISIS BEBAN KERJA, PERILAKU INDIVIDU, DAN PERSEPSI TERHADAP KINERJA KARYAWAN PT. HASJRAT ABADI MANADO. Jurnal EMBA: Jurnal Riset Ekonomi .... https://ejournal.unsrat.ac.id/index.php/emba/article/view/14243

Tang, X. (2018). Timing and compensation strategies in service recovery. Journal of Services Marketing, 32(6), 755-766. https://doi.org/10.1108/JSM-04-2017-0126

Tarcan, M. (2017). An analysis of the relationship between burnout, socio-demographic and workplace factors and job satisfaction among emergency department health professionals. Applied Nursing Research, 34, 40-47. https://doi.org/10.1016/j.apnr.2017.02.011

Taufiqurrohman, T. (2020). PENGARUH BUDAYA ORGANISASI DAN KOMITMEN ORGANISASI TERHADAP KINERJA KARYAWAN DENGAN ORGANIZATIONAL CITIZENSHIP BEHAVIOR .... e-repository.perpus.iainsalatiga.ac … http://e-repository.perpus.iainsalatiga.ac.id/7865/

Teng, C. (2020). Ethical work climate, organizational identification, leader-member-exchange (LMX) and organizational citizenship behavior (OCB): A study of three star hotels in Taiwan. International Journal of Contemporary Hospitality Management, 32(1), 212-229. 
https://doi.org/10.1108/IJCHM-07-2018-0563

Thoha, M. (2014). PERILAKU FANDALISME SISWA DI LEMBAGA PENDIDIKAN ISLAM. TADRIS: Jurnal Pendidikan Islam, 9(2), 287-306.

Tiara, S. (2020). PENGARUH ORGANIZATIONAL CITIZENSHIP BEHAVIOR DAN KOMITMEN

ORGANISASI TERHADAP KINERJA KARYAWAN PT JASA MARGA (PERSERO) TBK .... repository.umsu.ac.id. http://repository.umsu.ac.id/handle/123456789/14834

Tokhayatun, S. (2020). ANALISIS LINGKUNGAN KERJA, BUDAYA KERJA DAN KOMPENSASI TERHADAP SEMANGAT KERJA KARYAWAN TOSERBA YOGYA SLAWI.

repository.upstegal.ac.id. http://repository.upstegal.ac.id/1514/

Torida, A. (2012). Pengaruh Lingkungan Kerja Dan Karakteristik Individu Terhadap Motivasi Dan Kinerja Karyawan (Studi Kasus Pada Karyawan Plant $2 a$ Pt. Kertas Leces (Persero) .... repository.ub.ac.id. http://repository.ub.ac.id/id/eprint/115351

Torre, E. (2015). Internal and external equity in compensation systems, organizational absenteeism and the role of explained inequalities. Human Relations, 68(3), 409-440. https://doi.org/10.1177/0018726714528730

Trimisat, M. I. (2020). ... KERJA, DAN KOMITMEN ORGANISASIONAL TERHADAP ORGANIZATIONAL CITIZENSHIP BEHAVIOR (OCB)(Studi Kasus Pada Pegawai Kantor Pelayanan Pajak .... VOLATILITAS. http://ejournal.umpwr.ac.id/index.php/volatilitas/article/view/6322

Tuhagana, A. (2019). PENGARUH PERILAKU INDIVIDU TERHADAP PELAKSANAAN KESEHATAN DAN KESELAMATAN KERJA DI PT. XXX INDONESIA. Jurnal Manajemen \& Bisnis Kreatif. http://journal.ubpkarawang.ac.id/index.php/Manajemen/article/view/824

Tupamahu, F. A. S. (2018). Kecerdasan Spiritual, Kohesivitas Kelompok, Sebagai Pendorong Organizational Citizenship Behavior Dan Kinerja Karyawan. PELUANG. http://ejurnal.ukim.ac.id/index.php/peluang/article/view/323

Umar, H. (2019). Metode Riset Manajemen Perusahaan. Gramedia Pustaka Utama.

UTOMO, C. W., \& Wajdi, M. F. (2019). PENGARUH MODAL SOSIAL, ORGANIZATIONAL CITIZENSHIP BEHAVIOR, DAN KEPUASAN KERJA TERHADAP KINERJA KARYAWAN RUMAH SAKIT AMAL .... eprints.ums.ac.id. http://eprints.ums.ac.id/id/eprint/70844

Utomo, L. P. (2020). Pengaruh Profesionalisme, Budaya Kerja Terhadap Kinerja Internal Auditor, Dengan Kepuasan Kerja Sebagai Variabel Moderator. Jurnal Riset Manajemen Dan Bisnis .... http://ejournal.stiedewantara.ac.id/index.php/JMD/article/view/562

Valliappan, M. (2015). Organizational citizenship behavior of employees at butterfly gandhimathi appliances limited. International Journal of Economic Research, 12(2), 379-385. https://www.scopus.com/inward/record.uri?partnerID=HzOxMe3b\&scp=84937703361\&origin= inward

Victor, V. (2020). ANALISIS PENGARUH EFEKTIFITAS KERJA DAN BUDAYA KERJA TERHADAP PRESTASI KERJA GURU PADA SUNSHINE PLAYGROUP MEDAN. Jurnal Ilmiah SMART. http://stmb-multismart.ac.id/ejournal/index.php/JMBA/article/view/59

Wagenaar, A. (2015). Who gets fired, who gets re-hired: the role of workers' contract, age, health, work ability, performance, work satisfaction and employee investments. International Archives of Occupational and Environmental Health, 88(3), 321-334. https://doi.org/10.1007/s00420-0140961-6

Wahib, M. A. (2019). Pengaruh Budaya Perusahaan Terhadap Kinerja Karyawan Melalui Komitmen Organisasi Dan Organizational Citizenship Behavior (OCB) Pada PT. Varia Usaha .... Jurnal Ilmu Manajemen (JIM). https://jurnalmahasiswa.unesa.ac.id/index.php/jim/article/view/26253

Wakhyuni, E., \& Dalimunthe, A. A. (2020). PENGARUH ETIKA KERJA, PENGALAMAN KERJA, DAN BUDAYA KERJA TERHADAP PRESTASI KERJA PEGAWAI BADAN KESATUAN BANGSA, POLITIK $\quad . . . \quad$ In JUMANT. jurnal.pancabudi.ac.id. http://jurnal.pancabudi.ac.id/index.php/JUMANT/article/download/1056/943

Wang, T. (2018). How does Organizational Citizenship Behavior (OCB) Affect the performance of megaprojects? Insights from a system dynamic simulation. Sustainability (Switzerland), 10(6). https://doi.org/10.3390/su10061708

Wang, Y. (2016). Predictors of Organizational Citizenship Behavior: Ethical Leadership and Workplace Jealousy. Journal of Business Ethics, 135(1), 117-128. https://doi.org/10.1007/s10551-014-24805 
Wardhani, Y. (2020). PENGARUH GAYA KEPEMIMPINAN DAN PERILAKU INDIVIDU TERHADAP DISIPLIN KERJA SERTA DAMPAKNYA PADA KINERJA KARYAWAN BPS PROVINSI … repository.mahardhika-library.id. http://repository.mahardhikalibrary.id/id/eprint/1810

Wasiman. (2019). Model of competence and organizational citizenship behaviour (OCB) on performance of hotel employeees in batam city with organizational commitment as intervening variables. In Proceedings of the International Conference on Industrial Engineering and

Operations Management (pp. 2503-2509). https://www.scopus.com/inward/record.uri?partnerID=HzOxMe3b\&scp=85079480893\&origin= inward

Wediyasari, L. (n.d.). ... KARAKTER INDIVIDU DAN MOTIVASI KERJA TERHADAP KINERJA PEGAWAI DENGAN ORGANIZATIONAL CITIZENSHIP BEHAVIOR (OCB) SEBAGAI VARIABEL .... Repository.Unej.Ac.Id. https://repository.unej.ac.id/handle/123456789/95235

Wibawa, A. P., Riadi, S. S., \& ... (2017). Pengaruh karakteristik individu, kepuasan kerja dan loyalitas terhadap organizational citizenship behavior. Jurnal Ilmu Manajemen .... http://journal.feb.unmul.ac.id/index.php/JIMM/article/view/345

Wibowo, K. E., \& Wujoso, H. (2020). PENGARUH PEMAHAMAN AKREDITASI DAN KARAKTERISTIK INDIVIDU TERHADAP KINERJA KARYAWAN MEDIS DI RS KASIH IBU SURAKARTA. eprints.ums.ac.id. http://eprints.ums.ac.id/id/eprint/81806

Wibowo, S. (2010). Manajemen Kinerja-Edisi ketiga, Jakarta: PT. Raja Grafindo Persada. Widiyanto, G. (2018). Perilaku Individu Dalam Menghadapi Konflik \& Pengaruhnya Terhadap Kinerja Organisasi. Primanomics: Jurnal Ekonomi \& Bisnis. https://jurnal.buddhidharma.ac.id/index.php/PE/article/view/57

Widodo, A., Sunaryo, H., \& ABS, M. K. (2019). Pengaruh Kecerdasan Emosional, Komitmen Organisasional, Dan Organizational Citizenship Behavior Terhadap Kinerja Karyawan PT. Bank Muamalat Cabang ... Jurnal Ilmiah Riset Manajemen. http://www.riset.unisma.ac.id/index.php/jrm/article/view/4096

Widodo, D. S. (2017). PENGARUH BUDAYA ORGANISASI, KEPEMIMPINAN DAN KOMPENSASI MELALUI MOTIVASI KERJA TERHADAP KINERJA PEGAWAI. Jurnal Manajemen Motivasi. http://openjurnal.unmuhpnk.ac.id/index.php/jm_motivasi/article/view/723

Widyaningrum, M. E. (2020). The Mediating Role of Organizational Citizenship Behaviour (OCB) on the Effect of Work Culture and Leadership Style on Employee Performance (Study at the .... European Journal of Business and .... http://eprints.ubhara.ac.id/564/

Wildan, M. A., \& Safrizal, H. B. A. (2017). PENGARUH BUDAYA ORGANISASI, MOTIVASI KERJA DAN ORGANIZATIONAL CITIZENSHIP BEHAVIOR TERHADAP KINERJA

PEGAWAI PEMERINTAH $\quad . . \quad$ Competence $\quad . . . \quad \mathrm{https} / / / \mathrm{eco}-$ entrepreneur.trunojoyo.ac.id/kompetensi/article/view/3662

Yan, W. (2016). The Impact of Employee Compensation and Financial Performance on Nonprofit Organization Donations. The American Review of Public Administration, 46(2), 243-258. https://doi.org/10.1177/0275074014554000

Yandri, H., Fikri, M. K., \& Juliawati, D. (2019). Penerapan Perilaku Altruistik dalam Layanan Konseling Individu Oleh Guru Bimbingan dan Konseling di Sekolah. Tarbawi: Jurnal Ilmu .... http://ejournal.iainkerinci.ac.id/index.php/tarbawi/article/view/335

Yodsuwan, C. (2020). Exploring the drivers of organizational citizenship behaviors (OCB) among corporate meeting attendees. International Journal of Event and Festival Management, 12(1), 115. https://doi.org/10.1108/IJEFM-05-2020-0029

Yulianty, P. D. (2016). Pengaruh Kepemimpinan Transformasional dan Budaya Kerja Terhadap Kinerja Pegawai Dengan Komitmen Organisasional Sebagai Variabel Intervening (Studi .... repository.unpas.ac.id. http://repository.unpas.ac.id/14144/

Yunita, I. (2020). Kompetensi dan budaya kerja pustakawan menghadapi pasar bebas (Global market). Media Pustakawan. https://ejournal.perpusnas.go.id/mp/article/view/838 